Columbia Law School

Scholarship Archive

2016

\title{
Ask for the Moon, Settle for the Stars: What is a Reasonable Period to Comply with WTO Awards?
}

\author{
Petros C. Mavroidis \\ Columbia Law School, petros.mavroidis@unine.ch \\ Niall Meagher \\ Advisory Centre on WTO Law (ACWL), niallmeagher@hotmail.com \\ Thomas J. Prusa \\ Rutgers University, New Brunswick/Piscataway, prusa@rutgers.edu \\ Tatiana Yanguas \\ Advisory Centre on WTO Law (ACWL), tatiana.yanguas@acwl.ch
}

Follow this and additional works at: https://scholarship.law.columbia.edu/faculty_scholarship

Part of the Dispute Resolution and Arbitration Commons, and the International Trade Law Commons

\section{Recommended Citation}

Petros C. Mavroidis, Niall Meagher, Thomas J. Prusa \& Tatiana Yanguas, Ask for the Moon, Settle for the Stars: What is a Reasonable Period to Comply with WTO Awards?, EUROPEAN UNIVERSITY INSTITUTE, ROBERT Schuman Centre for Advanced Studies, Global Governance Programme Working Paper No. RSCAS 2016/ 45 (2016).

Available at: https://scholarship.law.columbia.edu/faculty_scholarship/2364

This Working Paper is brought to you for free and open access by the Faculty Publications at Scholarship Archive. It has been accepted for inclusion in Faculty Scholarship by an authorized administrator of Scholarship Archive. For more information, please contact scholarshiparchive@law.columbia.edu. 

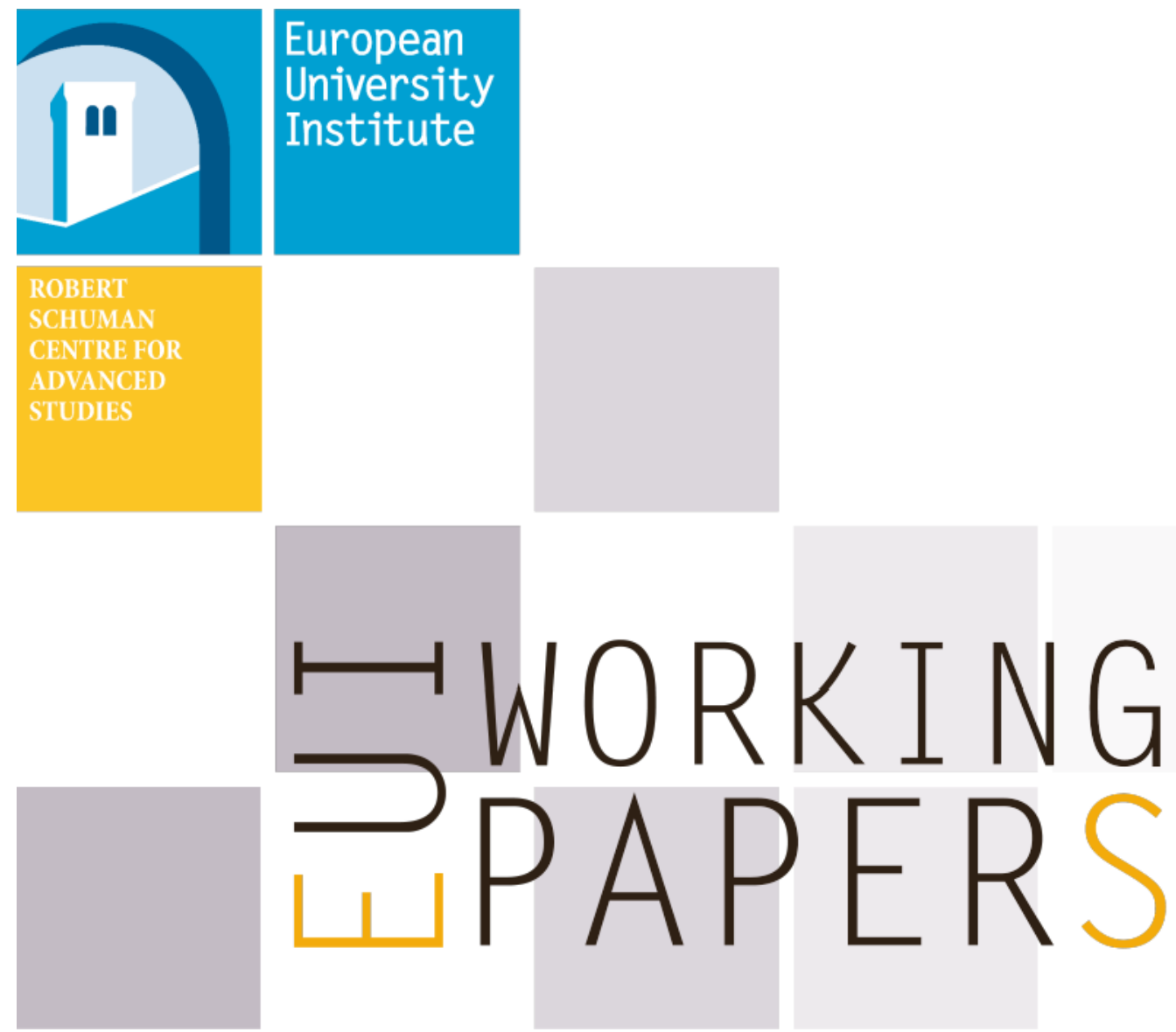

RSCAS 2016/45

Robert Schuman Centre for Advanced Studies Global Governance Programme-229

Ask for the Moon, Settle for the Stars. What is a Reasonable Period to Comply with WTO Awards?

Petros C. Mavroidis, Niall Meagher, Thomas J. Prusa and Tatiana Yanguas 
European University Institute

Robert Schuman Centre for Advanced Studies

Global Governance Programme

Ask for the Moon, Settle for the Stars.

What is a Reasonable Period to Comply with WTO Awards?

Petros C. Mavroidis, Niall Meagher, Thomas J. Prusa and Tatiana Yanguas

EUI Working Paper RSCAS 2016/45 
This text may be downloaded only for personal research purposes. Additional reproduction for other purposes, whether in hard copies or electronically, requires the consent of the author(s), editor(s). If cited or quoted, reference should be made to the full name of the author(s), editor(s), the title, the working paper, or other series, the year and the publisher.

ISSN 1028-3625

(C) Petros C. Mavroidis, Niall Meagher, Thomas J. Prusa and Tatiana Yanguas, 2016

Printed in Italy, September 2016

European University Institute

Badia Fiesolana

I - 50014 San Domenico di Fiesole (FI)

Italy

www.eui.eu/RSCAS/Publications/

www.eui.eu

cadmus.eui.eu 


\section{Robert Schuman Centre for Advanced Studies}

The Robert Schuman Centre for Advanced Studies (RSCAS), created in 1992 and directed by Professor Brigid Laffan, aims to develop inter-disciplinary and comparative research on the major issues facing the process of European integration, European societies and Europe's place in $21^{\text {st }}$ century global politics.

The Centre is home to a large post-doctoral programme and hosts major research programmes, projects and data sets, in addition to a range of working groups and ad hoc initiatives. The research agenda is organised around a set of core themes and is continuously evolving, reflecting the changing agenda of European integration, the expanding membership of the European Union, developments in Europe's neighbourhood and the wider world.

Details of the research of the Centre can be found on: http://www.eui.eu/RSCAS/Research/

Research publications take the form of Working Papers, Policy Papers, and e-books. Most of these are also available on the RSCAS website:

http://www.eui.eu/RSCAS/Publications/

The EUI and the RSCAS are not responsible for the opinions expressed by the author(s).

\section{The Global Governance Programme at the EUI}

The Global Governance Programme is one of the flagship programmes of the Robert Schuman Centre for Advanced Studies at the European University Institute (EUI). It aims to: build a community of outstanding professors and scholars, produce high quality research and, engage with the world of practice through policy dialogue. At the Global Governance Programme, established and early career scholars research, write on and discuss, within and beyond academia, issues of global governance, focussing on four broad and interdisciplinary areas: European, Transnational and Global Governance; Global Economics; Europe in the World; and Cultural Pluralism.

The Programme also aims to contribute to the fostering of present and future generations of policy and decision makers through its unique executive training programme, the Academy of Global Governance, where theory and "real world" experience meet. At the Academy, executives, policy makers, diplomats, officials, private sector professionals and academics, have the opportunity to meet, share views and debate with leading academics, top-level officials, heads of international organisations and senior executives, on topical issues relating to governance.

For more information: http://globalgovernanceprogramme.eui.eu 



\begin{abstract}
The World Trade Organization (WTO) dispute settlement process allows a defending Member a "reasonable period of time" (RPT) to implement any findings that its contested measures are inconsistent with WTO law. If agreement on this RPT cannot be reached, Article 21.3(c) of the Understanding on Rules and Procedures Governing the Settlement of Disputes (DSU) provides for the possibility of arbitration on the length of the RPT. The DSU provides limited guidelines on the RPT, stating only that it should not normally exceed 15 months. In practice, Arbitrators have developed the standard that the RPT should reflect the shortest possible period under the domestic legal system of the defending Member to make the changes necessary to comply with the WTO rulings. Our research confirms that in practice Arbitrators have determined this period by "splitting the difference" approximately between the periods suggested by the complaining and defending Member. In addition, the process appears to reward defending Members that request an RPT that exceeds the 15-month guideline in Article 21.3(c).
\end{abstract}

\title{
Keywords
}

WTO; Dispute Settlement; Reasonable Period of Time

JEL Classification: K40 

Ask for the moon but settle for the stars. Always ask for more than you really expect to get.

Ian Wilkinson

The Hitchhiker's Guide to Negotiations, p. 26

When the final result is expected to be a compromise, it is often prudent to start from an extreme position.

John Maynard Keynes

The Economic Consequences of Peace, p. 28

\section{Introduction*}

In this paper we inquire into the criteria that WTO Arbitrators have employed in order to calculate the reasonable period of time RPT in arbitrations under Article 21.3(c) of the DSU. The RPT is a key concept in WTO dispute settlement, and refers to the period that defendants will have in order to comply with adverse rulings of a WTO panel or the Appellate Body.

Using detailed information on every Article 21.3(c) case since the inception of the DSU in 1995 - a total of 34 disputes - we analyze the factors that have influenced the RPT decision. ${ }^{1}$ While Arbitrators take into account dispute-specific circumstances, we nonetheless find that, for all practical purposes, Arbitrators commonly take the path of compromise, opting for an RPT that approximately lies halfway between the time proposed by the complaining Member(s) and that by the defending Member.

We interpret the Arbitrators' tendency to "split the pie" as an approach that is not only consistent with the DSU's desire for fairness and balance but also allows both sides to inform domestic constituencies that the Article 21.3(c) process has incorporated their concerns and interests. In practice, however, this interpretation is perhaps somewhat naïve. Parties appear to have adapted to the Arbitrator's tendency to split the difference. We find that defending Members increasingly ask for an extremely long RPT. Even though the RPT virtually never exceeds 15 months defending Members often ask for more than 15 months and, consequently, generally receive a longer RPT than they would if they limited their request to the 15-month guideline.

Our analysis also indicates that given the fairly high degree of predictability of the outcome of an Article 21.3(c) proceeding, parties have strong incentives to agree on a negotiated RPT under Article 21.3(b), thereby avoiding the expense of an Article 21.3(c) arbitration.

This paper is structured as follows. In section 2 we present some general statistics on the use of Article 21.3(c); in sections 3 and 4 we discuss the legal framework, the constraints that Arbitrators must observe when deciding on the extent of the RPT. It is here that we establish that Arbitrators are left with substantial discretion and, hence, an examination of practice is necessary in order to extrapolate the criteria actually used to decide on the RPT. Sections 5 and 6 are dedicated to a discussion of practice, and this is where we establish that Arbitrators almost always offer each side a "moral" victory by splitting the difference between the complaining Members' bid and the defending Member's ask. Section 7 recaps our conclusions in brief.

The views expressed in this article are the personal academic views of the authors, who are fully responsible for all opinions and errors herein.

1 Our database spans the time period January 1, 1995 to May 31, 2016. The earliest Article 21.3(c) arbitration is Japan Alcoholic Beverages II (1996), and the last dispute is Peru - Agricultural Products (2015). Data is publicly available at www.wto.org. 


\section{The Use of Article 21.3(c)}

Before proceeding with our analysis of the RPT process, it is helpful to briefly review the use of Article 21.3(c) of the DSU. Other studies of DSU practice are relevant. Horn, et al. (2011) provide a general overview on the use of the DSU and characterize the actual time needed to adjudicate disputes. Peng (2008) offers a preliminary look at the use of Article 21.3(c).

In Table 1 we list the complainants involved in these disputes. As is the case with overall DSU activity, the European Union $^{2}$ (EU) and United States (US) are the two most active Article 21.3(c) complaining Members. We note that the total number of complaining Members (59) exceeds the number of Article 21.3(c) disputes (34) because multiple complaining Members are often involved (11 disputes had multiple complainants). In one arbitration, US - Offset Act (Byrd Amendment) (Article 21.3(c) of the DSU), there were eleven complaining Members.

Table 1 - Complaining Members in Article 21.3(c) Proceedings ${ }^{+}$

\begin{tabular}{lc} 
Complaining Members & No. of Disputes \\
EU & 11 \\
US & 7 \\
Canada & 6 \\
Japan & 5 \\
Mexico & 4 \\
Brazil, Korea, Thailand & 3 each \\
Argentina, Australia, Guatemala, & 2 each \\
Honduras, India & \\
$\begin{array}{l}\text { Antigua and Barbuda, Chile, China, } \\
\text { Ecuador, Indonesia, Panama, Viet Nam }\end{array}$ & 1 each \\
TOTAL & $\mathbf{5 9}$ \\
\hline $\begin{array}{l}\text { does not add-up to total number of proceedings because some disputes } \\
\text { involve multiple complainants }\end{array}$
\end{tabular}

Table 2 reports the defending Members in Article 21.3(c) proceedings. There is only one defending Member in each dispute so the total number of defendants matches the total number of disputes. Once again, as is the case with overall DSU activity, the US and EU are the two most frequent defending Members.

2 In disputes prior to 1 December 2009, the EU was referred to as the European Communities (EC). For ease of reference, in this paper we use the current term, except when referring to actual disputes prior to the change in nomenclature. 
Table 2 - Defending Members in Article 21.3(c) Proceedings

\begin{tabular}{lc} 
Defending Members & No. of Disputes \\
\hline US & 13 \\
EU & 5 \\
Canada & 3 \\
Chile, Japan & 2 each \\
$\begin{array}{l}\text { Argentina, Australia, Brazil, China, } \\
\text { Colombia, Dominican Republic, Indonesia, }\end{array}$ & 1 each \\
$\begin{array}{l}\text { Korea, Peru } \\
\text { TOTAL }\end{array}$ & $\mathbf{3 4}$ \\
\hline
\end{tabular}

Table 3 lists the covered agreements, which were the subject of Article 21.3(c) proceedings. As was the case with the list of complaining Members, the total number of covered agreements (55) exceeds the number of disputes because often multiple agreements have been found to be inconsistent in a single dispute. Specifically, 19 disputes involved a single agreement and 10 disputes involved two different agreements - most often the General Agreement on Tariffs and Trade (GATT 1994) and the Agreement on Implementation of Article VI of the General Agreement on Tariffs and Trade 1994 (Anti-Dumping Agreement). Four disputes involved three WTO covered agreements, and one dispute, US - Offset Act (Byrd Amendment) (Article 21.3(c) of the DSU), involved four WTO covered agreements.

Table 3 - Covered Agreements in Article 21.3(c) Proceedings ${ }^{+}$

\begin{tabular}{lc} 
Covered Agreements & No. of Disputes \\
GATT 1994 & 21 \\
Anti-Dumping Agreement & 9 \\
SCM Agreement & 6 \\
WTO Agreement & 3 \\
TRIPS Agreement & 3 \\
GATS & 3 \\
Agreement on Agriculture & 3 \\
SPS Agreement & 2 \\
Agreement on Safeguards & 2 \\
TRIMs Agreement & $\mathbf{1}$ \\
TBT Agreement & 1 \\
Agreement on Customs Valuation & 1 \\
TOTAL & $\mathbf{5 5}$ \\
\hline
\end{tabular}

${ }^{+}$does not add-up to total number of proceedings because some disputes involve multiple covered agreements 
In four disputes, the parties were able to reach an agreement regarding the RPT before the Arbitrator had completed its work. These arbitrations are dropped from the remaining analysis. ${ }^{3}$

\section{The Legal Framework}

The primary remedy available to successful complainants in WTO dispute settlement proceedings is that the defending Member must bring its WTO-inconsistent measures into compliance with WTO law. Naturally, this entails some changes in the defending Member's laws and regulations. Often, these changes cannot happen overnight. Accordingly, the DSU envisages that Members may have a RPT to bring their WTO-inconsistent measures into compliance.

Article 21.3(b) of the DSU provides the parties to the dispute with an opportunity to reach a mutual agreement on the RPT. If they cannot do so, however, Article 21.3(c) of the DSU provides for an arbitration to determine the RPT. ${ }^{4}$

The DSU provides only general guidance as to what this RPT should be. On the one hand, Article 21.3 of the DSU expresses a preference for immediate implementation. Only if that is impracticable, may the defending Member have a RPT to comply. Article 21.3(c) of the DSU notes that the RPT shall normally not exceed 15 months from the date of adoption of the underlying report. There is, however, no further express guidance as to how the RPT should be determined.

\subsection{The Objective Function of Article 21.3(c) of DSU}

Article 21.3 of the DSU, as noted above, regulates the process for establishing the RPT to implement recommendations and rulings of WTO dispute settlement panels and the Appellate Body. As also noted, immediate compliance with rulings (panel, or Appellate Body, as the case may be) is the preferred option. Realistically, immediate or even prompt compliance is not always in the cards. Either for innocuous reasons (e.g., administrative procedures that must be followed for a statute to be rescinded or amended), and/or political economy reasons (reluctance to implement/difficulties in building political consensus to implement adverse rulings), compliance more often than not does not take place immediately or even very quickly. Thus, an RPT becomes de facto a necessity. During the RPT, the defending Member may continue to apply the WTO-inconsistent measures without further consequences. Consistent case law suggests that the obligation for remedial action kicks in at the end of the RPT. ${ }^{5}$

If implementation were left to its discretion, the defending Member might procrastinate. The domestic interests that propelled it to pursue the WTO-inconsistent measures in the first place will wish to keep them in place as long as possible in order to continue to benefit from them. On the other hand, if the decision was left exclusively to the complaining Member, it might insist on an unrealistically short time for implementation, and it might even insist on immediate compliance. Where negotiations are unsuccessful, therefore, a process needs to be established where the opinions of both sides can be heard and reconciled.

3 They were the following Article 21.3(c) of the DSU proceedings: US - Zeroing (Japan), Dominican Republic Cigarettes, US - Softwood Lumber V, and US - Line Pipe. In these cases, a report of the proceedings was issued but no award was made. In US - Line Pipe, the US and Korea requested the Arbitrator to delay the issuance of the Arbitral Award in several occasions in order to allow time for additional bilateral discussions. See US - Line Pipe (Article 21.3(c) of the DSU), $\S \S 6$ and 8. There is no apparent common pattern explaining why the parties eventually agreed on the RPT during the arbitration proceedings. In general, we would expect a high degree of compliance of defending Members with mutually agreed RPTs, precisely because it was voluntarily agreed to proceed accordingly.

4 Palmeter, Mavroidis and Meagher (2016).

5 See, for example, the panel report on EC-Hormones (Article 22.6-EC) at $§ 38$. 
Article 21.3 of the DSU provides for a three-stage process. First, a Dispute Settlement Body $(\mathrm{DSB})^{6}$ meeting will be convened within 30 days from the adoption of the panel and Appellate Body (if any) reports. At that meeting, the complaining Member can propose a period which, if accepted by the defending Member, will be the RPT within which compliance should occur [Article 21.3(a) of the DSU)]. In practice, this occurs very rarely. Second, if the complaining Member's proposal is not accepted, the process moves to a second stage where the complaining and defending Member(s) can continue to negotiate an RPT for an additional 15 days and, if an agreement is reached, communicate their agreement to the DSB [Article 21.3(b) of the DSU)]. Third, if 45 days have elapsed since the adoption of the final report and no agreement has been reached, the parties may have recourse to arbitration. ${ }^{7}$ In this case, an Arbitrator will determine the RPT [Article 21.3(c) of the DSU)].

\subsection{Last Resort}

The system established by Article 21.3 of the DSU and outlined above makes it clear that recourse to arbitration in order to calculate the RPT is the last resort. It is available only when a bargained solution proves to be out of reach. If recourse to arbitration were not available when bilateral agreement proved elusive, implementation and compliance could otherwise stall at this stage. This is a very realistic scenario in light of the tenant of Article 23.2 of the DSU, which bans all unilateral qualifications of illegality when in presence of a dispute.

The preference for a bargaining solution though, is not inconsequential. We expect complaining Members to request a shorter, and the defending Member a longer period. Nevertheless, where they can be reached, there is a high likelihood that bilateral solutions will be implemented, precisely because parties have voluntarily agreed to proceed accordingly. On the other hand, we would rationally expect Arbitrators to find a middle ground, choosing an RPT between the suggested periods, rather than calculate de novo and arrive, eventually, at an entirely independent period. By doing so, Arbitrators show some respect for the statutory preference for a bargaining solution by trying to accommodate the preferences of the parties to the dispute to the extent possible. Furthermore, from a pure administrative point of view as well, it is easier to use the suggested deadlines as points of reference, rather than start from scratch and first develop the appropriate criteria before, based on them, calculate the RPT de novo.

\subsection{Who Appoints the Arbitrator?}

According to footnote 12 to Article 21.3(c) of the DSU, the parties to the dispute must attempt to agree on an Arbitrator. If they succeed, they will communicate the name to the DSB. ${ }^{8}$ If, 10 days after the matter has been referred to arbitration, the parties have not agreed on the Arbitrator, the DirectorGeneral (DG) of the WTO must appoint the Arbitrator within a further 10 days.

The DG must consult with the parties to the dispute on their preferences regarding the identity of the Arbitrator. However, the DG is not obliged to accept the preferences or suggestions of the parties. While the process is confidential, we cannot be certain whether the eventual choice corresponds to a name or the characteristics proposed by the parties. As noted in the following section, however, a convention has developed in practice that the Arbitrator is a sitting or former member of the Appellate

6 The DSB is the body that administers the DSU, and each WTO Member has one delegate participating therein.

7 There is no obligation to do so, as parties to the dispute can continue to negotiate in the hope of reaching a bilateral agreement.

8 The DSB is the WTO body administering the DSU. Every WTO Member has one delegate appointed at this body. Its decisions are taken by consensus, except, as is well known, the decisions regarding recourse to panels/Appellate Body and adoption of panel/Appellate Body reports, and requests for adoption of countermeasures (suspension of concessions). 
Body. Of the 30 disputes to be analyzed we found that the parties agreed to an Arbitrator in 18 disputes; the Arbitrator was appointed by the DG in the other 12 disputes.

\subsection{Identity of Arbitrators}

Footnote 13 to Article 21.3(c) of DSU states:

The expression "arbitrator" shall be interpreted as referring either to an individual or a group.

So far the Arbitrator has always been an individual and never a group. As the first Arbitrators were Appellate Body members, the convention has developed that the Arbitrator is usually a current or former Appellate Body member. Only in one recent arbitration, US - Shrimp II (Viet Nam), the Arbitrator was not an acting or former member of the Appellate Body. In that case, the Arbitrator was a member of the original panel. ${ }^{9}$ (see Table 4)

Table 4 - Identity of Arbitrators, 1996-2015

\begin{tabular}{lc} 
Identity & No. of Disputes \\
Current AB member & 22 \\
Former AB member & 7 \\
Other & 1 \\
\hline
\end{tabular}

\subsection{Task of Arbitrators}

The task of the Arbitrator is simply to determine the duration of the RPT. The Arbitrator in USOffset Act (Byrd Amendment) (Article 21.3(c) of the DSU) put it eloquently, when stating:

$\ldots$ it is not part of my mandate to determine or even to suggest the manner in which the United

States is to implement the recommendations and rulings of the DSB (§48).

A few lines later in the same report, we read:

... my task is not to look at how implementation will be carried out, but to determine when it will

be done ( $\$ 53$, emphasis in the original).

The Arbitrator in EC-Chicken Cuts (Article 21.3(c) of the DSU) expressed the same view in even more succinct terms:

... my task focuses on the when not on the what ( $\$ 49$, emphasis in the original).

There is no "firewall" of course, between the "when" and the "what". The means at the disposal of a WTO Member to implement will undeniably influence the duration of the RPT. A WTO Member might, for example, have to observe constitutional deadlines or other requirements in order to amend its laws. The Arbitrator has no mandate to require or even to request defending Members to disrespect their constitution or other domestic legal requirements in implementing panel and Appellate Body rulings and recommendations.

9 This was Simon Farbenbloom, an Australian government official. In EC-Hormones (Article 21.3(c) of the DSU), the Brazilian Ambassador Celso Lafer was nominated to be Arbitrator jointly with former Appellate Body member Said ElNaggar; however, he was unable to accept this nomination. The arbitration was solely conducted by Mr. El-Naggar. 
The reference to the "when" and the "what" then, is better understood as a standard of review device. Whereas the Arbitrator has to take domestic legal constraints as given, it has discretion to decide on the duration of the RPT within the constraints circumscribed by domestic law. ${ }^{10}$

In Chile - Price Band System (Article 21.3(c) of the DSU), the Arbitrator captured this point to perfection when stating that the period of time should be the (§34):

... shortest possible within the legal system of the Member to implement the relevant recommendations and rulings of the DSB.

\subsection{Guidelines for Arbitrators}

The Arbitrator will not start work from a clean slate. As noted above, the preference is for immediate implementation. In addition, Article 21.3(c) of the DSU states that:

... the reasonable period of time... should not exceed 15 months...

The word "should" leaves little doubt that the period that the Arbitrator decides in individual disputes could be either longer or shorter than the 15-month guideline. This was confirmed by the Arbitrator's Award in Chile - Price Band System (Article 21.3(c) of the DSU). There, the Arbitrator, not only endorsed the view that the 15-month period was a mere "guideline", but further underscored that the "particular circumstances" of a specific case take precedence, and might dictate a shorter or longer period after all (§34):

Notwithstanding this "guideline" ... I must ultimately be informed by the "particular circumstances" of a given case ...

The Arbitrator concluded that its task was to identify the "shortest possible [time] within the legal system of the Member to implement the relevant recommendations and rulings of the DSB", in the light of the "particular circumstances" of the dispute". "This has become the guideline used by subsequent Arbitrators.

Thus, in EC-Bananas III (Article 21.3(c) of the DSU), the Arbitrator recommended a period that exceeded the 15-month period (\$20). Of all 34 Article 21.3(c) disputes through 2015, however, ECBananas III is the only dispute to date in which the RPT awarded has exceeded 15 months.

We now turn to how in practice the Arbitrators have gone about the task of identifying the shortest possible time within the legal system of the defending Member. We start with a discussion of the pertinent procedural issues, before moving to a discussion of the circumstances that have influenced the Arbitrators in their determinations of the RPT.

\subsection{Procedural Issues}

Article 21.3(c) of the DSU requests from Arbitrators to issue their report within 90 days from the date of adoption of recommendation and rulings of the final report. In practice, parties to the dispute can agree to a longer period and inform the Arbitrator accordingly. This happens very frequently, for two reasons. First, the parties may wish to extend the time available to agree on the RPT in order to have enough time to implement adverse rulings, and thus reduce the possibility for inadequate implementation and recourse to countermeasures. Second, once the arbitration commences, the parties may wish to extend the deadline to facilitate a mutually convenient schedule for submissions and the

10 The defending Member is not required to recourse to any extraordinary or "urgency" procedures envisaged in its domestic law to bring the WTO-inconsistent measure into compliance with WTO law. See e.g., Award of the Arbitrators in US-COOL (Article 21.3(c) of the DSU), §70; Brazil-Retreaded Tyres (Article 21.3(c) of the DSU), §48, and KoreaAlcoholic Beverages (Article 21.3(c) of the DSU), \$42.

11 Award of the Arbitrator, Chile — Price Band System (Article 21.3(c) of the DSU), §34. 
hearing before the Arbitrator. In practice, this means that the arbitrations usually get started too late to make it feasible for the Arbitrator to complete its work within the 90-day deadline.

As with other aspects of WTO dispute settlement proceedings, the default rule in Article 21.3(c) proceedings is that the party making a claim carries the associated burden of proof (Appellate Body Report, US - Wool Shirts and Blouses). Arbitrators have underscored the consequences of the defendant's failure to rebut the original proposal. We explain.

Recall that complaining Members have recourse to Article 21.3(c) of the DSU because the defending Member has not agreed with the period proposed by the complaining Member(s). Before the Arbitrator, the defending Member will, of course, repeat its disagreement with that period (otherwise a settlement would have occurred). The starting point is thus, the period suggested by the complaining Member. Once the complaining Member has proposed the benchmark, it is for the defending Member to explain why it is not correct and to make a counterproposal. If the Arbitrator finds that the counterproposal is unreasonable, it will base its decision on the totality of evidence (see US - Gambling (Article 21.3(c) of the DSU) (\$31). ${ }^{12}$

In effect, this means that, in common with many other aspects of WTO dispute settlement proceedings, issues of burden of proof are ultimately not terribly legally significant: each party must in practice assume the burden of adducing sufficient evidence to support its own positions. At the end of the day, WTO judges will decide on preponderance of evidence without pointing who should bring forward the requested evidence each time by raising an arrow to this effect towards either the complainant or the defendant.

\section{The Reasonableness Standard and Attendant Circumstances}

The discussion so far has established that the Arbitrator has considerable discretion to define the RPT during which compliance should occur. In what follows, we discuss how this has worked in practice, and how Arbitrators have exercised their discretion. To do this, we will first explain the generic standard that Arbitrators have developed, and then see how they have applied it to specific disputes. The standard developed calls for "reasonableness". It has been further disaggregated into specific criteria (often referred to as "attendant circumstances") on which Arbitrators have based their calculation of the RPT.

\subsection{A Reasonableness Standard}

In US - Hot Rolled Steel (Article 21.3(c) of the DSU), the Arbitrator laid down the standard that has been applied in all similar disputes $(\$ 25)$ :

... a "reasonable period" must be interpreted consistently with the notions of flexibility and balance that are inherent in the concept of "reasonableness", and in a manner that allows for account to be taken of the particular circumstances of each case.

Circumstances are of course idiosyncratic elements in each and every case. And yet the rationale for taking into account some of them on board, while rejecting others, reveals the scaffolding on which "reasonableness" stands. Case law has established, however, that there is one element that it would be unreasonable to take into account when calculating the RPT. In Indonesia - Autos (Article 21.3(c) of the $D S U$ ), the Arbitrator held that the RPT is not meant to provide breathing space to the domestic industry that will suffer from the compliance/adjustment of the WTO-inconsistent measure. This is

12 The Arbitrator in US-Offset Act (Byrd Amendment) (Article 21.3(c) of the DSU) confirmed this (§44). 
because, in virtually every case in which a measure has been found to be WTO-inconsistent, some degree of adjustment by the domestic industry of the Member concerned will be necessary (§23). ${ }^{13}$

In what follows, we examine the criteria (attendant circumstances) upon which the Arbitrators have relied in order to calculate the RPT.

\subsection{Administrative vs. Legislative Procedures Required}

We have stated above that, although the mandate of the Arbitrator is limited to a calculation of the period of time during which compliance should occur, it will not put into question the intricacies of domestic law that will be employed to this effect. ${ }^{14}$ Practice reveals that Arbitrators have routinely made a distinction between disputes where, under domestic law, the defending Member must use legislative as opposed to administrative procedures. The rationale is that usually longer periods are required to change laws than to change regulations or other administrative instruments.

When legislative measures are required, the calendar of the legislature might be relevant in calculating the RPT (US - Offset Act (Byrd Amendment) (Article 21.3(c) of the DSU) at §70). ${ }^{15}$ Conversely, when administrative procedures are required, the timing of forthcoming elections is irrelevant for the determination of the RPT (US - Stainless Steel (Mexico) (Article 21.3(c) of the $D S U)$ at $\$ 62)$.

Based on the distinction between administrative and legislative procedures, Arbitrators have consistently decided on shorter periods when the former are required. The reports issued in CanadaPharmaceutical Patents (Article 21.3(c) of the DSU) (\$49), and Chile - Price Band System (Article 21.3(c) of the DSU) (\$38) illustrate this point.

Also, in Brazil - Retreaded Tyres (Article 21.3(c) of the DSU), the Arbitrator did not exclude that the judiciary may be involved in implementation (\$68).

\subsection{Complexity of the Implementing Measure}

An overlapping issue concerns the complexity of the implementing measures employed. In CanadaPharmaceutical Patents (Article 21.3(c) of the DSU), the Arbitrator accepted that the complexity of the measure, and not necessarily the complexity of the procedure to be employed (although the two are interlinked), was a factor that should be taken into account when calculating the period (\$50). However, the mere fact that a WTO Member is called to comply with an international obligation has been dismissed as a factor of complexity (US - Offset Act (Byrd Amendment) (Article 21.3(c) of the $D S U)$ at $\S 70) .{ }^{16}$

13 This was confirmed by the Arbitrator in EC - Export Subsidies on Sugar (Article 21.3(c) of the DSU) ( $\S 92 \mathrm{ff}$ ).

14 In some cases, in order to establish the time by which a Member must comply, it will be necessary to take into account the manner in which the Member proposes to do so as an element of analysis to determine the RPT. See e.g., Award of the Arbitrator, Peru-Agricultural Products (Article 21.3(c) of the DSU), § 3.6.

15 This was considered in cases where a new Congress has not yet convened at the time when the arbitration was initiated. See Awards of the Arbitrators in US - Section 110(5) Copyright Act (Article 21.3(c) of the DSU), $\$ 45$ and US - 1916 Act (Article 21.3(c) of the DSU), §44.

16 This was confirmed by the Arbitrator in EC - Chicken Cuts (Article 21.3(c) of the DSU) and Brazil -Retreaded Tyres (Article 21.3(c) of the DSU), $\S \S 52$ and 82 , respectively. 


\subsection{Developing Country Status}

\subsubsection{Developing Country Acting as Complainant}

In this case, the intuition is that complaining developing countries will suffer more than developed countries from untimely compliance, since they are more likely to be reliant on the export income being lost as a result of the defending Member's WTO-inconsistent measures. This is of course, a proposition that may not always be grounded in reality. In EC-Export Subsidies on Sugar (Article 21.3(c) of the DSU), the Arbitrator accepted Brazil's argument to the effect that delayed implementation would lead to increase unemployment and accordingly reduced the period of time (§§99ff.).

A mere invocation, without proof, of economic harm or loss does not suffice. Unlike Brazil, in the sugar dispute, in US - Gambling (Article 21.3(c) of the DSU), Antigua and Barbuda did not produce any evidence showing increased unemployment because of the US' delayed implementation. Consequently, the Arbitrator did not reduce the RPT on these grounds (\$62). In any event, there are some issues that will not be influenced by the status of the complainant as a developing country. For example, in US-OCTG Sunset Reviews (Article 21.3(c) of the DSU), the Arbitrator refused to reduce the period of time because the legislative procedure required in order to bring the measures into compliance would be the same regardless of whether the complainant was a developing country ( $\$ 52)$.

This reflects the practical reality that if the legal standard applied by the Arbitrator is that the defending Member should implement within the shortest time possible under its legal system, this time cannot be further shortened depending on whether the complaining Member is a developed or developing Member. ${ }^{17}$

\subsubsection{Developing Country Acting as Defendant}

The concern here is that developing countries may have non-performing administrations, and thus, other things being equal, might require longer periods to comply with adverse rulings than developed WTO Members. Once again, the intellectual legitimacy of this proposition is quite shaky, for various reasons. Developing countries is an amorphous concept anyway, and some developing countries at the top end of the scale look more like developed than developing countries (developing country status at the WTO is self-defining). Moreover, for good reasons (e.g., scarce administrative capacity) developing countries might opt for shorter procedures than more developed countries.

Nevertheless, in Indonesia - Autos (Article 21.3(c) of the DSU), the Arbitrator gave "full weight" to the developing country status of the defending Member, Indonesia, and the fact that it was experiencing an exceptional dire economic and financial situation. As a result, the Arbitrator determined a longer RPT of an additional period of six months over and above the six-month period required for the completion of Indonesia’s domestic rule-making process $(\$ 24)$.

\subsubsection{Complainant and Defendant are both Developing Countries}

This issue arose in Chile - Price Band System (Article 21.3(c) of the DSU), since both complainant (Argentina), and defendant (Chile) were developing countries. Under the circumstances, the Arbitrator decided not to take into account at all their developing country status $(\S 56){ }^{18}$

17 See also Award of the Arbitrator, US - COOL (Article 21.3(c) of the DSU), §§99 and 100.

18 The same was determined by the Arbitrator in Colombia - Ports of Entry (Article 21.3(c) of the DSU) $\$ \$ 106$ and 107 , where Panama was the complaining and Colombia the defending Member; and recently in Peru-Agricultural Products (Article 21.3(c) of the DSU), where Guatemala was the complaining and Peru the defending Member, §3.43. 
In EC - Tariff Preferences (Article 21.3(c) of the DSU), the EC requested a longer RPT arguing that the award of the Arbitrator would affect third party developing countries and LDCs that were beneficiaries of the EC's GSP scheme that was at issue in the dispute. The Arbitrator did not consider this to be a relevant particular circumstance (\$59).

\subsection{The Societal Importance of the Measure}

In Chile - Price Band System (Article 21.3(c) of the DSU), the Arbitrator faced a novel issue. It was suggested that the fact that the price band system at issue had been used for years to calculate prices of imports, its long-term integration in Chilean agricultural policies, and the popular opposition its withdrawal would provoke argued for a longer period. The Arbitrator considered that

...[a]ll WTO disputes are 'contentious' domestically at least to some extent; if they were not, there would be no need for recourse by WTO Members to dispute settlement.

Thus, simple contentiousness may not be a sufficient consideration under Article 21.3(c) for a longer period of time (\$47). Nevertheless, the Arbitrator accepted Chile's argument for a longer period of time, considering that the price band system was "so fundamentally integrated into the policies of Chile" and its modification or repeal had an "unique role and impact on Chilean society" that a longer RPT was warranted (\$48). Similar arguments have been raised in 40 per cent of all Article 21.3(c) proceedings without success. ${ }^{19}$

\subsection{The Clock Ticks from the Date of Adoption}

The Arbitrator in EC-Chicken Cuts (Article 21.3(c) of the DSU) observed that four months had passed since the adoption of the final report. The Arbitrator considered that this elapsed time must be included in the RPT, since the defending Member should not remain idle once the report is adopted and pending decision on the RPT. Instead, the Member should be striving towards the implementation of the adverse rulings from the date of adoption, since the duty to comply does not depend on the calculation of the RPT but on the adoption of the report (\$66).

\subsection{Embedded Reasonableness}

In US - COOL (Article 21.3(c) of the DSU), the inconsistent measure came under the ambit of the Agreement on Technical Barriers to Trade (TBT Agreement). Article 2.12 of the TBT Agreement provides that Members must allow a certain period of time between the issuance of certain TBT measures and their entry into force. In the underlying dispute, the US was found to have acted inconsistently with its obligations by not respecting this time period. The issue then arose whether the Arbitrator should take this minimum period into account in determining the RPT for the US to implement its new, WTO-consistent measure. The complaining Members, whom this requirement was designed to protect, indicated that they did not want to benefit from it with respect to the measures taken to implement. The Arbitrator therefore decided not to include this period in the calculation of the RPT $(\S 121)$.

19 See annexed Table. For instance, this argument has been rejected in e.g., Awards of the Arbitrator in EC - Export Subsidies on Sugar (Article 21.3(c) of the DSU), §102, and Colombia - Ports of Entry (Article 21.3(c) of the DSU), $\S \S 102$ and 103 . 


\section{Timeliness of Article 21.3(c) in Practice}

We now consider the timeliness of Article 21.3(c) dispute process itself. Are the time guidelines mentioned in Article 21.3(c) reflected in actual practice? Are Article 21.3(c) proceedings completed in a timely fashion?

\subsection{Lengthy Negotiations}

In practice, disputes do not generally proceed to arbitration immediately after the period of 45 days allowed for negotiations under Article 21.3(b) has elapsed. In fact, only a single dispute has gone to the Arbitrator within 45 days, Chile - Price Band System (Article 21.3(c) of the DSU). The distribution of time elapsed from the adoption of the reports until the initiation of the arbitration is given in Figure 1. As seen, about half of the disputes do not go to arbitration until more than 70 days after the adoption of the final report, far longer than one would expect given the language in Articles 21.3(b) and (c) of the DSU. The average negotiation period is 75 days. Remarkably, one dispute, Brazil - Retreaded Tyres (Article 21.3(c) of the DSU), did not go to arbitration until day 170 after adoption - almost four times longer than the 45-day rule. Some of the reasons for this were outlined above.

Figure 1 - Length of Time to Start Arbitration

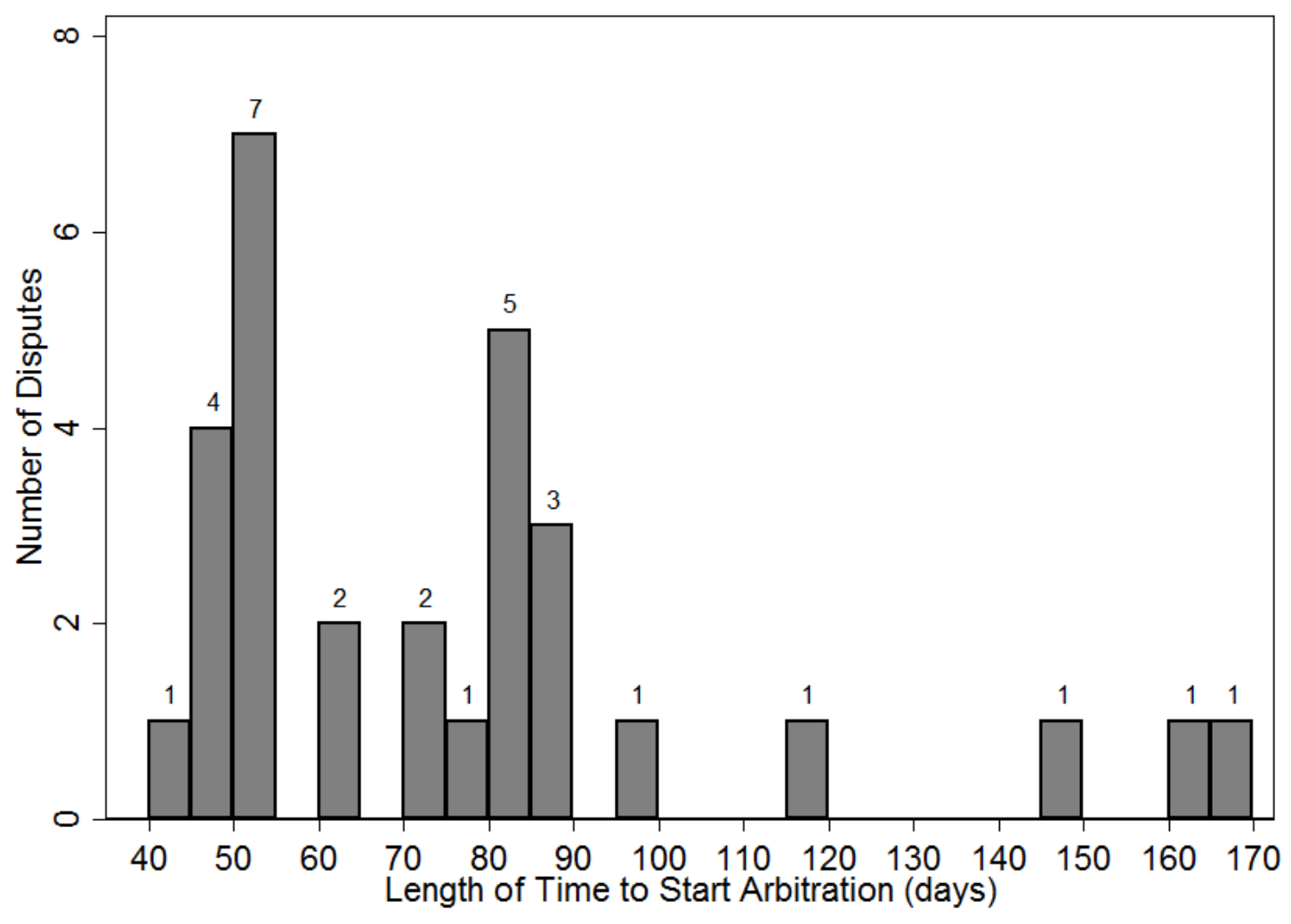

While the efforts of the parties to negotiate an RPT are commendable, the long delay in moving to arbitration could have consequences for the determination of the eventual RPT. Article 21.3(c) gives no reason to expect an Arbitrator to account for the negotiation time when making his/her RPT decision. Given that the expectation is the defending Member begins work on implementation as soon as the report is adopted, we see no reason why the Arbitrator should account for the time spent 
negotiating with the complaining Member. Taking the negotiation period into account might give defending Members an incentive to prolong negotiations.

On the other hand, the Arbitrator might not want to penalize the defending Member for intense good faith negotiations and thus might (at least partially) incorporate the time spent on negotiations into the calculation. After all, it is presumably more efficient if the parties reach an agreement on RPT. In addition, if the negotiation time is not taken into account, a long negotiation period will simply mean the defending Member will subsequently have less time to implement after the Arbitrator's award is announced. An Arbitrator might not feel comfortable making a decision that leaves only weeks after the announcement of the RPT for the defending Member to complete its implementation. Alternatively, the long negotiation period could reflect the complexity of the implementation. And, complex cases might receive longer RPT. If so, the longer negotiation period and the longer RPT might both reflect complexity rather than strategic delay. Finally, a lengthy negotiating period constrains the RPT that may be requested by the complaining Member: if the negotiations last, say, 120 days, it is not practical for the complaining Member to request an RPT of, say, 90 days.

In these circumstances, we would expect to find that Arbitrators generally award longer RPTs in cases where the negotiation period was longer. In Figure 2 we present a scatterplot of the length of time spent negotiating (the $x$-axis) and the eventual RPT award (the $y$-axis). Each dot corresponds to an Article 21.3(c) dispute. Dots further the right have longer negotiation periods and higher dots correspond to longer RPTs. Visually the figure suggests a positive relationship indicating that Arbitrators appear to award longer RPTs in cases where longer time is spent negotiating before having recourse to arbitration. We also include an Ordinary Least Squares (OLS) fitted regression line to visually depict the correlation. ${ }^{20}$

Figure 2 - Delay in Starting Arbitration and RPT Award

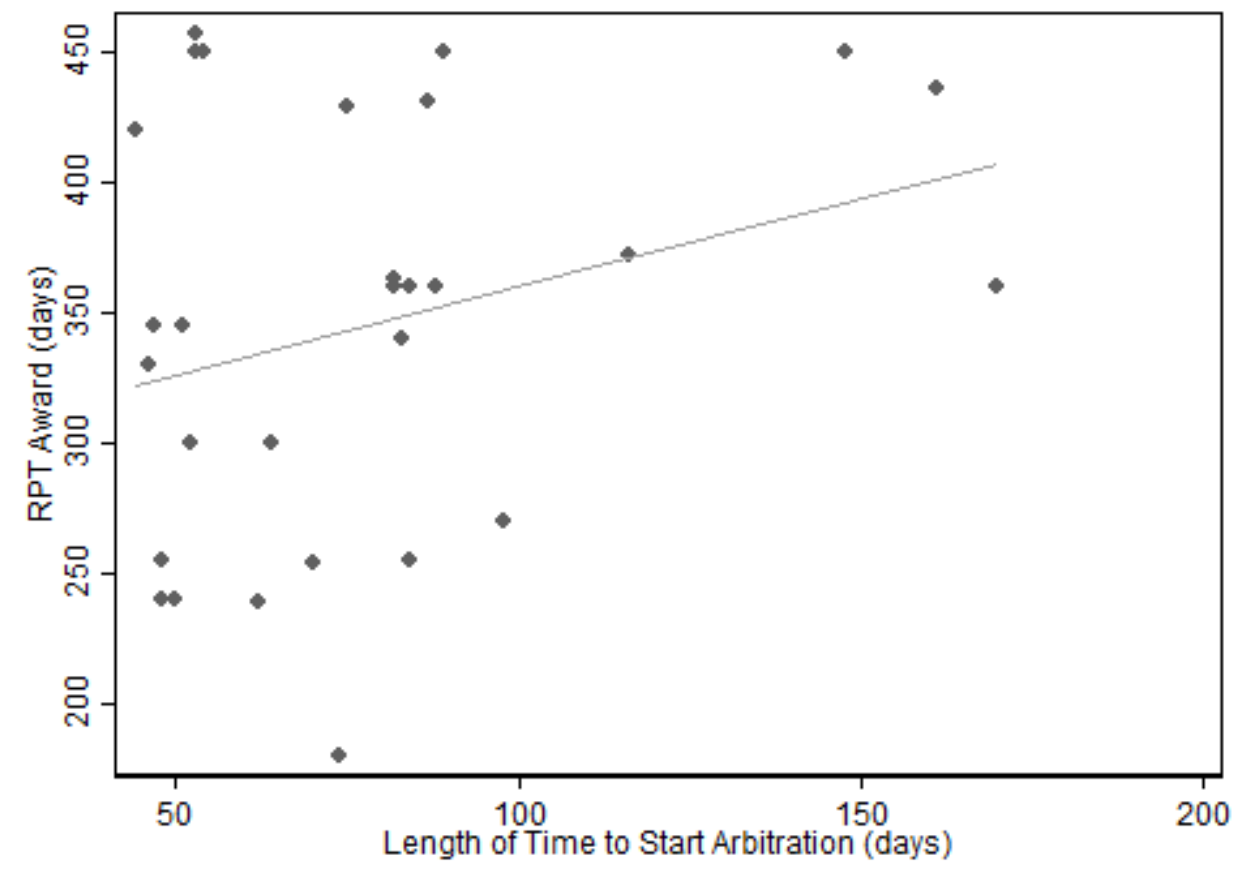

20 We present formal statistical analysis below where we refine our estimates. We note here that in this simple univariate regression depicted in the figure the impact of the length of time negotiating has a positive and statistically significant impact on the RPT award. 


\subsection{The Arbitration Process}

Arbitrators are expected to issue their award within 90 days from the date of adoption of the final report. As explained above, this schedule is unrealistically short. Part of the reason for the lengthy time required for the Arbitrator to issue the award was discussed in the previous subsection - parties often do not request arbitration until long after the 45-day guideline. Consequently, it is unrealistic to think an Arbitrator could finish his/her award within the 90-day guideline: if the Arbitrator were to begin his/her work on, for example, day 70 , one cannot reasonably expect him/her to issue the award by day 90 .

However, long negotiation periods are only part of the story. The reality is, perhaps not surprisingly, Arbitrators take far longer than the time suggested by Article 21.3(c) of the DSU. Figure 3 provides evidence. Here we report the length of time associated with the arbitration proceedings. The minimum time taken for an arbitration proceeding is 51 days. The average time taken is 75 days. In 10 per cent of the disputes, the arbitration proceedings have lasted 90 days or more.

\section{Figure 3 - Length of Arbitration Proceedings}

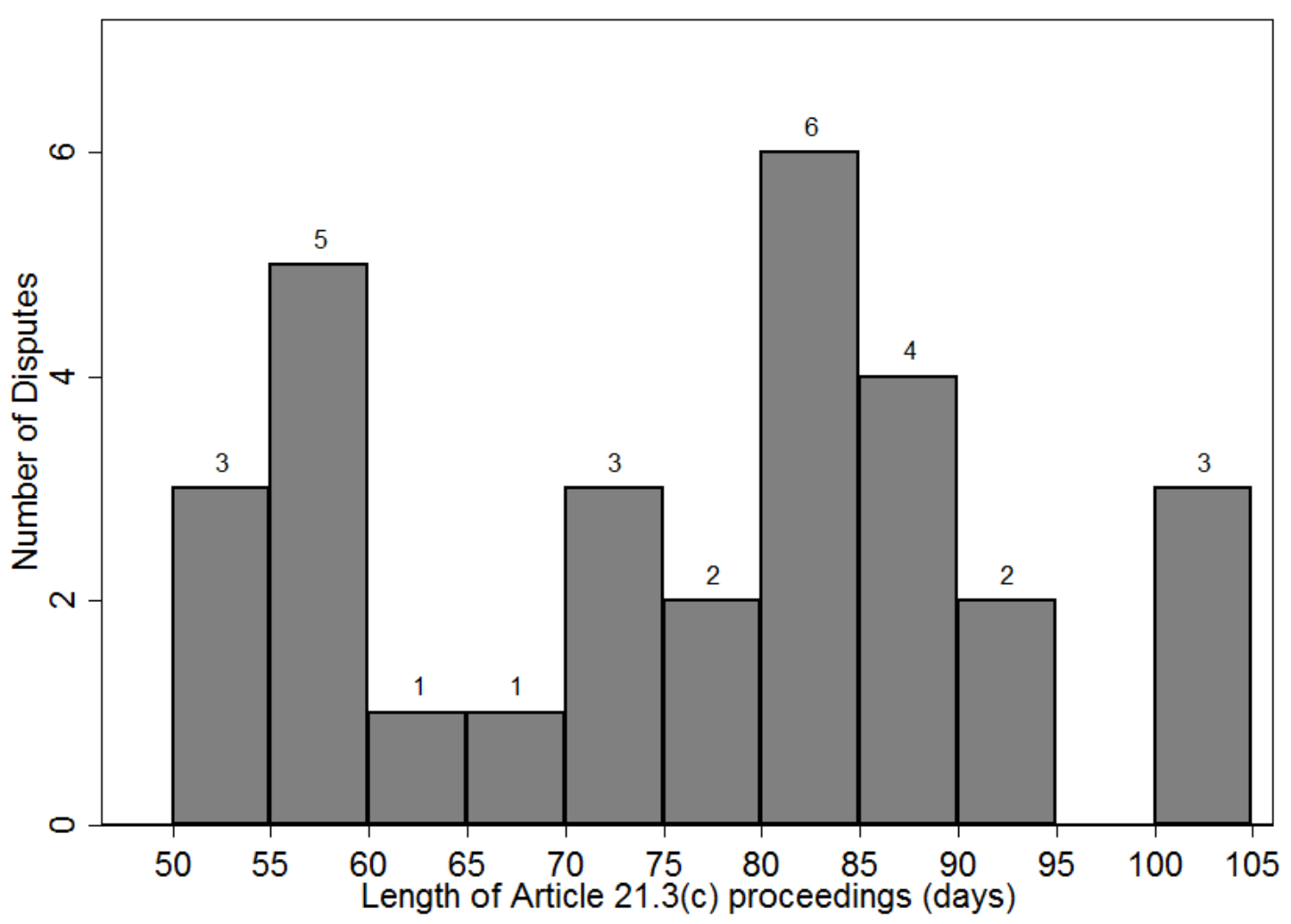

As is the case with the duration of the negotiations, the time taken to complete the arbitration process could also have important consequences for the eventual RPT. Interestingly, however, no such connection is found in the data. We examined the relationship between the length of the arbitration proceedings and the RPT award. We found no statistical correlation. This suggests the Arbitrator does not incorporate the time spent deliberating in the calculation of the RPT award.

\subsection{Overall Time to RPT Award}

Given the above two findings, it should not come as a surprise that we find that the Arbitrator's report was never issued within the 90-day window (Figure 4). The minimum time required for the 
Arbitrator's award as measured from the date of adoption of the recommendation and rulings of the DSB is over 100 days and the average (median) time is 148 (139) days. Remarkably, in more than 10 per cent of the proceedings, the Arbitrator's award was not issued until more than 180 days had passed, more than twice as long as the timeframe specified in Article 21.3(c) of the DSU.

\section{Figure 4 - Total Time to RPT Award Decision}

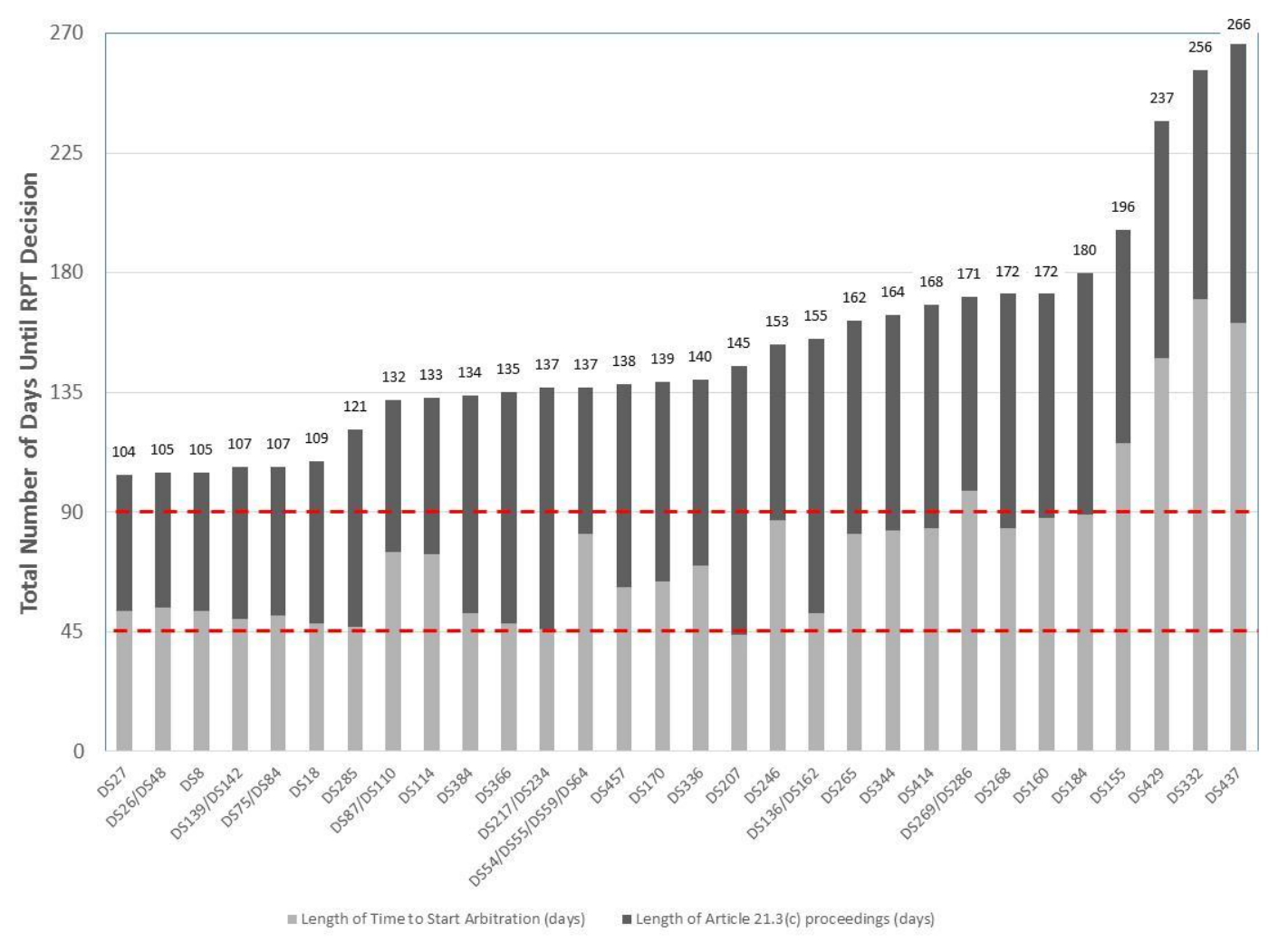

\section{RPT Awards}

In spite of the lengthy process, the RPTs awarded by Arbitrators generally fall within the Article 21.3(c) guidelines. Of the 30 disputes, all but one had an RPT that was less than or equal to 450 days (i.e., the 15-month guideline in Article 21.3(c)). The exception was EC-Bananas III (Article 21.3(c) of the DSU), in which the RPT was just seven days longer than the 15-month guideline. We now investigate in statistical terms which factors appear to have influenced the awards on the determination of the RPT.

\subsection{Factors Influencing the RPT}

\subsubsection{Developing Country Status}

Article 21.2 of the DSU provides that "particular attention should be paid to matters affecting the interests of developing country Members with respect to measures which have been subject to dispute settlement." As noted above, this attention could manifest itself in developing country Members obtaining a longer RPT when they are the defending Member and a shorter RPT when they are a complaining Member. 
Interestingly, there is little evidence for either hypothesis. We find that disputes with developing countries as complaining Members have an average RPT of 342 days, as compared to an average of 349 days for those where the complaining Member is developed (Figure 5). Where the defending Member is a developing country, we find an average RPT of 344 days, as compared to an average of 346 days for disputes in which the defending Member is a developed country (Figure 5). Neither difference is statistically significant.

Figure 5 - Average RPT Award

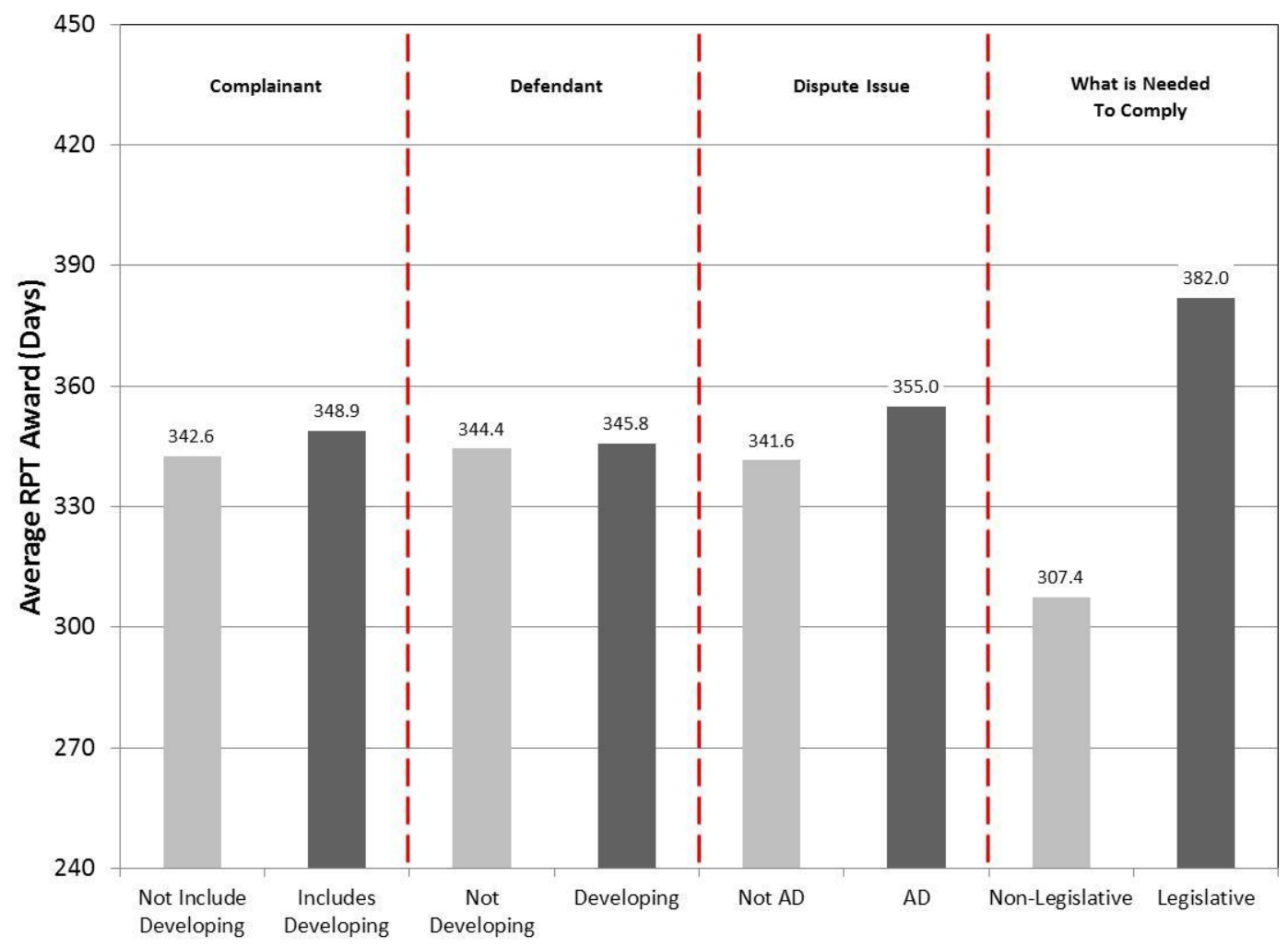

\subsubsection{Covered Agreements}

As shown in Table 3, a large number of covered agreements have been the subject of disputes that have resulted in Article 21.3(c) proceedings. We examined whether the covered agreement at issue in an arbitration had any impact on the RPT. The answer is no. We examined the RPT awarded for disputes involving each covered agreement and found no meaningful or statistically significant differences. Figure 5 shows the results for disputes involving one covered agreement - the AntiDumping Agreement. As shown in Table 3, cases involving anti-dumping measures are frequently the subject of Article 21.3(c) proceedings. Arbitrations in disputes involving the Anti-Dumping Agreement resulted in an average RPT of 355 days, as compared to an average RPT of 342 days for disputes not involving the Anti-Dumping Agreement. This difference of approximately two weeks is not statistically significant. Or, as another example, arbitrations in disputes involving the GATT 1994 resulted in an average RPT of 353 days versus an average RPT of 333 days for arbitrations in disputes not involving the GATT 1994. While this difference is slightly larger than the difference found for disputes involving the Anti-Dumping Agreement, it is nevertheless not statistically significant. 


\subsubsection{Legislative vs. Non-Legislative Compliance}

We find that compliance requires some type of legislative action in about half of the arbitrations. As we noted above, even a casual review of Article 21.3(c) Awards makes it clear that Arbitrators routinely determine longer RPTs when the defending Member must use legislative, rather than simply administrative procedures to comply. The casual empiricism is confirmed in the data (Figure 5). Disputes requiring legislative action to implement had an average RPT of 382 days versus an average RPT of 307 days for disputes where legislative action was not needed. This different of almost eleven weeks is, notably, statistically significant.

Table 5 - RPT Requests

\begin{tabular}{lccccc} 
& \multicolumn{2}{c}{ Non-Legislative } & & \multicolumn{2}{c}{ Legislative } \\
\cline { 2 - 3 } \cline { 5 - 6 } & $\begin{array}{c}\text { Complaining } \\
\text { Member }\end{array}$ & $\begin{array}{c}\text { Defending } \\
\text { Member }\end{array}$ & & $\begin{array}{c}\text { Complaining } \\
\text { Member }\end{array}$ & $\begin{array}{c}\text { Defending } \\
\text { Member }\end{array}$ \\
Average & 183 & 568 & & 234 & 556 \\
Median & 170 & 450 & & 210 & 540 \\
Min & 90 & 330 & & 180 & 422 \\
Max & 300 & 1395 & & 300 & 1170 \\
\hline
\end{tabular}

The need for legislative action influences not just the Arbitrator's RPT but also what the parties propose for the RPT (see Table 5). Specifically, when we look at the requests for RPTs in these cases, we see that complaining Members seem to incorporate the fact that the RPT will be longer in disputes requiring legislative action (234 days versus 183 days). This seems like reasonable bargaining on behalf of the complaining Members.

By contrast, we find little difference in the average RPT requested by defending Members for legislative vs. non-legislative implementation. Digging deeper, however, we find a large difference in the requested RPT when we look at the median rather than the mean. Notably, the median RPT request by defending Members is 450 days where no legislative changes are needed, but this increases to 540 days if legislative action is needed. Regardless whether we look at the mean or the median, it is clear that defending Members systematically ask for an RPT that is far longer than the 450-day guideline.

\subsection{Strategic Bargaining}

Complaining and defending Members appear to understand how their requests affect the RPT award. In Figure 6 we depict the parties' requests and the Arbitrator's awards for the RPT. In this figure, we order the disputes by duration of defending Member's RPT request. The solid circles denote the complaining Members' request; the solid squares denote the defending Member's request. The red dash line reflects the Arbitrator's RPT. 
Figure 6 -RPT Requests and Arbitrator's Award

(disputes ordered by size of defending Members' RPT request)

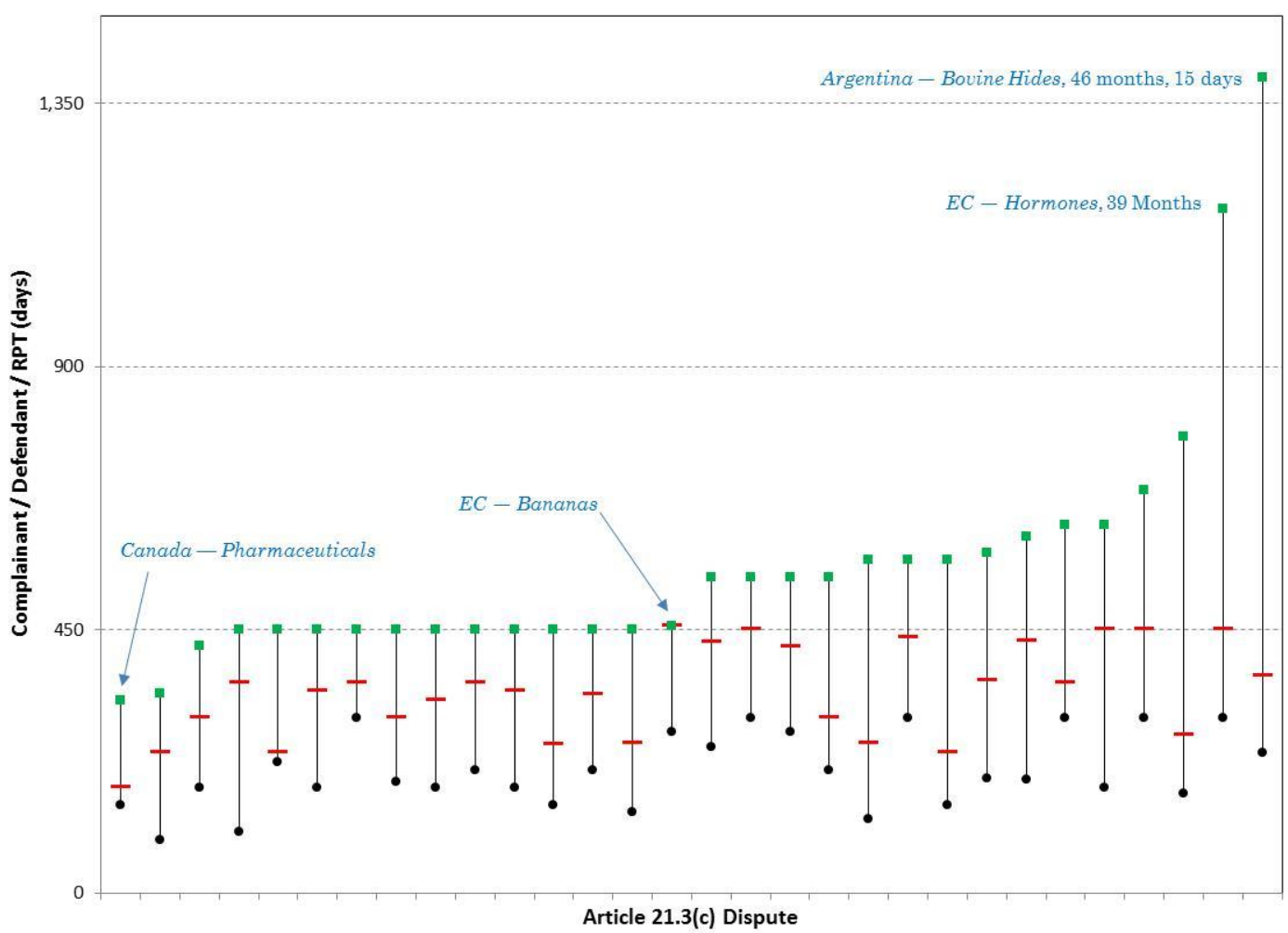

Several clear patterns can be seen. First, defending Members always request more time than the complaining Members. ${ }^{21}$ The complaining Members' average request is 208 days and defending Members' average request is 562 days (last row, Table 6).

Second, there has only been a single dispute, EC - Bananas III (Article 21.3(c) of the DSU), in which the Arbitrator did not "split the difference". In that case, the defending Member asked for and received an RPT of 15 months and seven days. Interestingly, EC - Bananas III (Article 21.3(c) of the $D S U$ ) is also noteworthy because it is the only dispute where the RPT exceeded the 15-month guideline. In other words, while the 450-day guideline is not a mandated maximum, for all practical purposes, Arbitrators have acted as if the RPT is constrained not to exceed 450 days.

We define the "spread" as the difference between the complaining and defending Members' requests. The Arbitrator's decision can simply be characterized as how much of the difference given to each party. As shown in in the last row of Table 6, on average, the Arbitrator's RPT award very nearly splits the difference in half - the defending Member receives 44 per cent, and the complaining Member receives 56 per cent of the difference. ${ }^{22}$

21 In one case, Canada - Pharmaceuticals (Article 21.3(c) of the DSU), the complaining Member (the EC) asked for "less than 12 months" and the defending Member asked for 11 months. It is unclear how to interpret the EC's vague request. In our analysis, for purposes of completeness, we assume that the EC's the request was five months. While our choice of five months is admittedly arbitrary, we note that the Arbitrator's RPT was 6 months, so it seems sensible to assume the EC's RPT request was interpreted by the Arbitrator as a date no more than six months. Our choice of five months is consistent with the "split the difference" approach, which we observe in nearly all cases.

22 As an exception to the average trend, in EC-Hormones (Article 21.3(c) of the DSU) and Argentina - Hides and Leather (Article 21.3(c) of the DSU), the difference between the complaining and defending Members' requests was not "split" in half. This is because the requests of the defending Members in the mentioned cases were extraordinary long. The defending Members in these disputes justified their requests on certain attendant circumstances that were rejected by the 
When we divide the cases depending on whether legislative action is required, we see the split is almost exactly half-way for cases requiring legislative implementation (51.4 per cent). However, the split is not quite so even when the case does not require legislative action (36.8 per cent). When we compare the "share of spread" in the upper parts of the table, it becomes clear this is mostly due to the relatively low share when the defending Member asks for more than 450 days (just 29.5 per cent).

Table 6 - RPT Requests and Arbitrator's Award

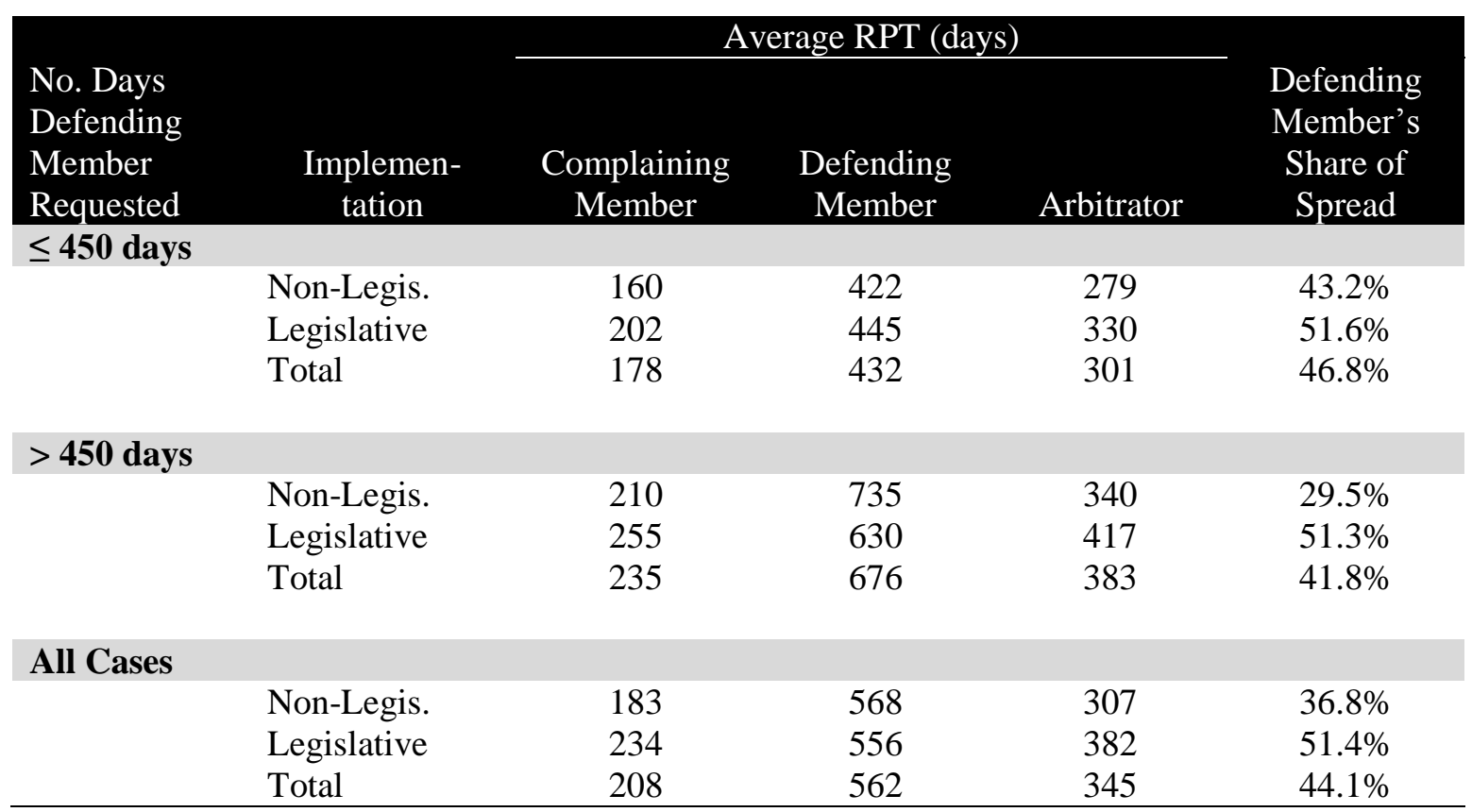

Third, the defending Member often asks for more than 15 months. In Table 6 we divide the disputes where the defending Member requests (i) no more than 450 days (14 disputes); and (ii) more than the 450 days (16 disputes). Fascinatingly, even though there is little reason why a defending Member should expect to receive more than 450 days, in more than half the cases, the defending Member nevertheless requests more than the 450-day guideline. Moreover, in these 16 disputes, the defending Members' requests averaged 676 days. In two cases, EC-Hormones (Article 21.3(c) of the DSU) and Argentina - Hides and Leather (Article 21.3(c) of the DSU), the requests exceeded three years.

While the 15-month period is only a guideline, in practice, the Arbitrators appear to treat the 15month period as the maximum RPT. The particular circumstances of the disputes, to date at least, have not warranted a systematic expansion of the RPT beyond 15 months. So, while defending Members often claim their case is unique and that a very long RPT is warranted, Arbitrators generally have not agreed.

(Contd.)

Arbitrator. In EC-Hormones (Article 21.3(c) of the DSU), the EC requested a RPT of 39 months as it needed to complete a hormone-specific and residue-specific risk assessment in order to implement the compliance measure. The Arbitrator rejected the request of the EC. He stated that granting additional time for risk assessment would have been contrary to "prompt compliance" and to compliance with the obligations of the SPS Agreement. He noted that the obligation to implement measures based on risk assessment commenced in 1995 when the WTO Agreement came into force and not when a final report was adopted by the DSB ( $\$ 40$ and 41). In Argentina - Hides and Leather (Article 21.3(c) of the $D S U)$, Argentina requested a RPT of 46 months. Argentina submitted that the compliance measure affected the heart of its tax system and the Law on Fiscal Solvency. In Argentina's view the restructuration of its tax system would have aggravated its liquidity problems in time of recession and would therefore need to be done progressively (across three financial years), especially considering its developing country Member status. The Arbitrator rejected Argentina's request. He established that the compliance measure was limited to specific DSB rulings and not to the bulk of measures targeted to overcome the Argentine economic recession. He also questioned the causal relation between the compliance measure and the economic situation in Argentina ( $\$ 44-49,49$, and 51). 
Nevertheless, the statistics in Table 6 suggest that there is some value to requesting a long RPT. For instance, for those cases where the RPT requested was less than 450 days, we see that the Arbitrators have awarded an average of 301 days. By contrast, when the defending Member asks for more than 450 days, the Arbitrators have awarded an average RPT of 383 days - 82 days longer than when the defending Member asks for less than 450 days. We see the same pattern when we divide the cases into those with and without legislative implementation. The disparity is seen for both cases requiring legislative implementation (417 vs. 330 days) and those not requiring legislative action (340 vs. 279 days). There is little doubt that requests for longer RPTs generally result in awards of longer RPTs.

Furthermore, for all practical purposes, the Article 21.3(c) process has evolved to the point where every case is deemed (by the defending Member) as warranting an extraordinarily long RPT. Figure 7 depicts similar information as presented in Figure 6. In Figure 7, however, the disputes are ordered chronologically. As seen, while defending Members have always asked for long RPTs, they now tend to do so in every case. Amazingly, the most recent dispute in which the defending Member requested an RPT of less than 15 months was Canada - Patent Term (Article 21.3(c) of the DSU) in 2000, over 15 years ago! There have been 18 Article 21.3(c) disputes since that time and in each one the defending Member asked for at least 15 months and, in two thirds of the cases, the defending Member has asked for more than 15 months.

\section{Figure 7 -RPT Requests and Arbitrator's Award}

(disputes ordered by chronological date)

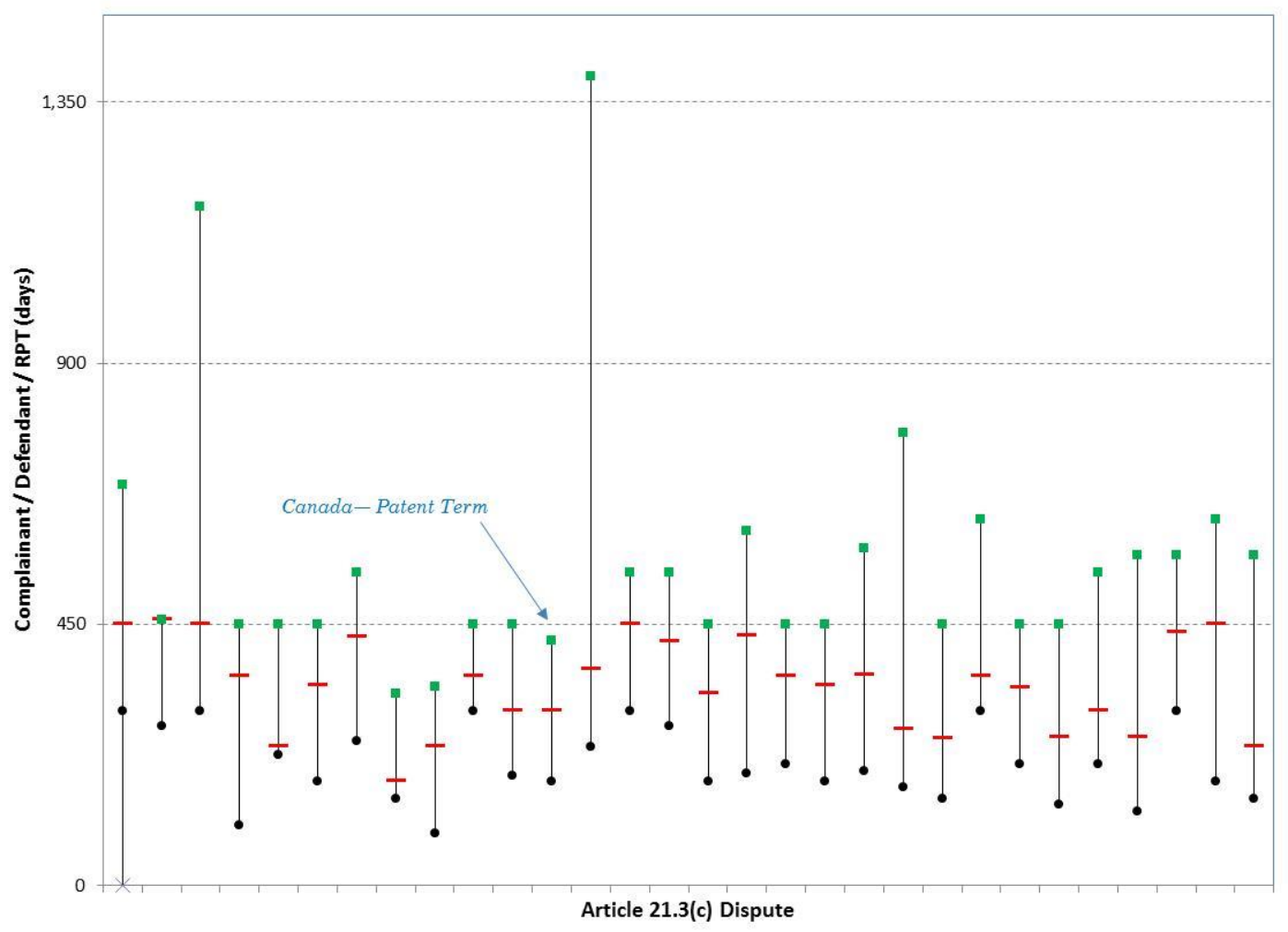

We believe the propensity of the defending Members to request RPTs exceeding the 15-month guideline reflects their understanding of what the Arbitrator does - namely, splitting the difference rather than computing an award de novo. If the Arbitrator is going to split the difference, why should the defending Member not ask for a longer RPT than it might perhaps reasonably expect to receive? 
Consider the early Article 21.3(c) proceedings. In the 12 cases through 2000 (i.e., cases up to and including Canada - Patent Term), in only three was the RPT awarded 450 days (or more): Japan Alcoholic Beverages II, EC - Bananas III, EC - Hormones. In each of these cases, the defending Member asked for more than 450 days. In only one of the remaining nine cases (Chile - Alcoholic Beverages), did the defending Member request more than 450 days. Interestingly, the RPT awarded in Chile - Alcoholic Beverages was the largest of the other nine cases (429 days), still less than the 450day guideline.

The data suggests that there is a return to a defending Member requesting longer RPTs. Thus, as often is the case when negotiating, there is a value to strategically asking for more than one can reasonably expect to receive. We document this in Table 7.

To get a sense of the extent to which requesting a longer RPT may influence the outcome, we partition the cases into four groups based on the following criteria: (i) whether or not legislative action is required: and (ii) whether or not the defending Member requested an RPT of more than 450 days. We then consider the following thought experiment. What if the Arbitrator treated all requests for RPTs longer than 450 days as if the RPT requested was 450 days? That is, what if the 450-day guideline operated as a cap on the RPT that could be requested or, more simply, as a cap on what can be considered?

Given that we found the "share of the spread" varied depending on the length of the RPT requested by the defending Member, we adjust the defending Member's share of the spread to equal that when the requests are less than 450 days. The alternative share of spread is given in the final column in Table $6 .^{23}$ The results are given in Table 7 . For cases not requiring legislative approval, we estimate the average RPT would have been 313 days instead of 340 days, a difference of 27 days. For cases requiring legislative action, we estimate the average RPT would have been 356 days instead of 417 days, a difference of 61 days.

Table 7 - Arbitrator's RPT Awards (days)

\begin{tabular}{|c|c|c|c|c|}
\hline \multicolumn{5}{|c|}{ Defending Member Request } \\
\hline & $\leq 450$ days & & lays & \\
\hline & Actual RPT & $\begin{array}{l}\text { Actual } \\
\text { RPT }\end{array}$ & $\begin{array}{c}\text { "What If" } \\
\text { RPT }^{*}\end{array}$ & $\begin{array}{l}\text { Additional } \\
\text { Days }\end{array}$ \\
\hline Non-Legislative & 279 & 340 & 313 & 27 \\
\hline Legislative & 330 & 417 & 356 & 61 \\
\hline Total & 301 & 383 & 337 & 46 \\
\hline
\end{tabular}

Overall, our analysis suggests the defending Member's decision to request an RPT longer than the 450-day guideline results in an RPT award that is 10 per cent to 20 per cent longer than it would otherwise be.

\section{Concluding Thoughts}

Article 21.3(c) gives the Arbitrator considerable discretion to define the RPT during which compliance should occur. We have established how Arbitrators have exercised their discretion embracing flexibility and balance, or more broadly, by adopting the concept of reasonableness. We then examined the "attendant circumstances" that may influence the Arbitrator's calculation of RPT.

23 For instance, for cases not requiring legislative action, the share was 29.5 per cent for those with long RPT requests versus 43.2 per cent for those with RPT requests of no more than 450 days. 
Practice reveals that Arbitrators have distinguished between disputes where, under domestic law, the defending Member must use legislative action as opposed to administrative procedures, and have consistently granted longer RPT when legislative action is needed. Other criteria such as whether the complaining and/or defending Members are developing economies or the specific covered agreement seem to have mattered less in practice.

Based on our review of all RPT awards for cases between January 1, 1995 and May 31, 2016, a couple of important insights emerge. First, there is a strong tendency for the Arbitrator to "split the difference" between the RPTs proposed by the complaining and defending Members. Interestingly, while there is some variation from case to case, on average, the Arbitrator awards an RPT that commonly lies about half-way between the two parties' proposals, especially in Article 21.3(c) cases involving legislative means of implementation. Second, we find that defendants have responded to the Arbitrator's apparent "split the difference" approach by increasing their requests for RPTs too far in excess of the 450-day guideline in Article 21.3(c). In fact, the average RPT requested in such cases was 676 days. We find that requests for longer RPTs have resulted in RPT awards that are approximately 30-60 days longer.

Our analysis also suggests that the approach taken by Arbitrators is one that could, in practice, be duplicated by the parties to a dispute in their negotiations under Article 21.3(b) of the DSU. Indeed, statistics indicate that the average RPT negotiated under Article 21.3(b) is 9.68 months, whereas the average RPT awarded by Arbitrators under Article 21.3(c) is 11.43 months. ${ }^{24}$ When adjustment is made for "easy" cases in which implementation does not take a long time and agreement is easily reached on the RPT, these periods are roughly the same. This suggests that our analysis is also reflected in the practical approach taken by Members in negotiating an RPT. The fact that the average RPT awarded by Arbitrators is longer than the average negotiated RPT may suggest (i) that the cases that go to arbitration involve more complicated implementation or compliance; and (ii) that the "rewards" available for requesting a longer RPT may be attractive in some cases.

It is debatable whether our review of Article 21.3(c) is consistent with the interpretation offered by Horn, Maggi, Staiger (2010) whose model approach suggests that what Arbitrators have done could be viewed as some form of 'completion' of the incomplete nature of Article 21.3. On one hand, it is unclear whether the authors had in mind instances like this one, or whether their model was confined to analysis operated in panel and Appellate Body reports exclusively. If we were to set this observation aside, in a way 'completion' has occurred through the development of criteria, the 'attendant circumstances', which will help the Arbitrator calculate the RPT. On the other hand, of course, as our analysis shows, at the end of the day, the only predictable outcome is that the difference will be eventually split. One might thus, rationally wonder whether the various criteria used actually affect the outcome of calculation or, conversely, it is the splitting of the difference that matters most (irrespective of the factors affecting the RPT), which we believe to be the case.

\footnotetext{
24 These statistics were retrieved from www.worldtradelaw.net
} 


\section{References}

Horn, Henrik, Louise Johannesson and Petros C. Mavroidis. 2011. "The WTO Dispute Settlement System 1995-2010: Some Descriptive Statistics," Journal of World Trade 45(6)): 1107-1138.

Horn, Henrik, Giovanni Maggi and Robert W. Staiger. 2010. "Trade Agreements as Endogenously Incomplete Contracts." American Economic Review, 100(1): 394-419.

Keynes, John Maynard. 1920. The Economic Consequences of the Peace. New York, Harcourt, Brace and Howe.

Palmeter, David N., Petros C. Mavroidis, and Niall Meagher. 2016. Dispute Settlement in the WTO, Practice and Procedure, Third Edition, Cambridge, Cambridge University Press.

Peng, Shin-yi, 2008 "How Much Time Is Reasonable - The Arbitral Decisions under Article 21.3(c) of the DSU", Berkeley Journal of International Law 26(1): 323-351.

Wilkinson, Ian. 2001. The Hitchhiker's Guide to Negotiation, Washington DC., AACC Press. 
PARTICULAR CIRCUMSTANCES RAISED BY THE DEFENDING MEMBER IN ARTICLE 21.3(C) DSU ARBITRATIONS

\begin{tabular}{|c|c|c|c|c|c|c|c|c|c|c|c|}
\hline $\begin{array}{l}\text { Dispute Number } \\
\text { [21.3c)] }\end{array}$ & $\begin{array}{l}\text { Dispute Name } \\
[21.3 c)]\end{array}$ & $\begin{array}{c}\text { Defendant is a } \\
\text { developing country }\end{array}$ & $\begin{array}{l}\text { Implementation } \\
\text { measure is complex }\end{array}$ & $\begin{array}{l}\text { Implementation } \\
\text { process is complex } \\
\text { (multi-step and } \\
\text { sequential process) }\end{array}$ & $\begin{array}{l}\text { Implementation } \\
\text { measure is } \\
\text { contentious } \\
\text { domestically }\end{array}$ & $\begin{array}{c}\text { Standard } \\
\text { legislative and } \\
\text { regulatory } \\
\text { practices linked to } \\
\text { transparency and } \\
\text { due-process are } \\
\text { needed for } \\
\text { implementation }\end{array}$ & $\begin{array}{c}\text { Institutional } \\
\text { changes, elections, } \\
\text { congressional } \\
\text { schedule affect } \\
\text { promptness of } \\
\text { implementation }\end{array}$ & $\begin{array}{c}\text { Broader legislative } \\
\text { or regulatory } \\
\text { reform, or support } \\
\text { measures are needed } \\
\text { for full } \\
\text { implementation } \\
\text { (r) }=(\text { (reform),(s)=(su } \\
\text { pplementary } \\
\text { means),(b)=(both) }\end{array}$ & $\begin{array}{c}\text { Structural market } \\
\text { imbalanceas and } \\
\text { domestic } \\
\text { adjustments should } \\
\text { be accounted for }\end{array}$ & $\begin{array}{l}\text { Workload of } \\
\text { implementing } \\
\text { authority affects } \\
\text { implementation }\end{array}$ & $\begin{array}{l}\text { Risk-assessment is } \\
\text { needed to full } \\
\text { implementation }\end{array}$ \\
\hline $\begin{array}{l}\overline{5} \\
\bar{w} \\
\hat{n}\end{array}$ & \begin{tabular}{|l} 
Peru - Agricultural \\
Products
\end{tabular} & yes & yes & yes & yes & yes & & yes $(\mathbf{S})$ & & & \\
\hline 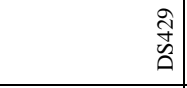 & $\begin{array}{l}\text { U.S. - Shrimp II } \\
\text { (Viet Nam) }\end{array}$ & & yes & yes & & & & & & yes & \\
\hline 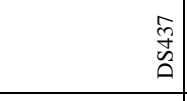 & \begin{tabular}{|l} 
U.S. - \\
Countervailing \\
Measures (China) \\
\end{tabular} & & yes & yes & & yes & & & & yes & \\
\hline 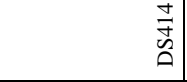 & China-GOES & yes & & yes & & yes & & yes $(\mathrm{S})$ & & & \\
\hline $\begin{array}{l}0 \\
\infty \\
\tilde{\hat{n}} \\
\hat{n}\end{array}$ & U.S. - COOL & & yes & yes & & yes & & & & & \\
\hline $\begin{array}{l}0 \\
0 \\
\tilde{n} \\
\hat{n}\end{array}$ & $\begin{array}{l}\text { Colombia - Ports of } \\
\text { Entry }\end{array}$ & yes & yes & yes & yes & & & yes $(\mathbf{S})$ & & & \\
\hline 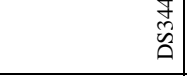 & $\begin{array}{l}\text { U.S. - Stainless } \\
\text { Steel (Mexico) }\end{array}$ & & yes & yes & & & yes & & & & \\
\hline 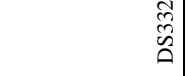 & \begin{tabular}{|l} 
Brazil - Retreaded \\
Tyres
\end{tabular} & & yes & yes & & & & yes $(\mathrm{S})$ & & yes & \\
\hline 岕 & Japan - DRAMS & & & yes & & yes & & & & & \\
\hline $\begin{array}{l}\tilde{N} \\
\tilde{\hat{n}}\end{array}$ & \begin{tabular}{|l} 
US - Zeroing \\
(Japan)
\end{tabular} & $\begin{array}{l}\text { agreement reached } \\
\text { between the parties }\end{array}$ & $\begin{array}{l}\text { agreement reached } \\
\text { between the parties }\end{array}$ & $\begin{array}{l}\text { agreement reached } \\
\text { between the parties }\end{array}$ & $\begin{array}{l}\text { agreement reached } \\
\text { between the parties }\end{array}$ & $\begin{array}{l}\text { agreement reached } \\
\text { between the parties }\end{array}$ & $\begin{array}{l}\text { agreement reached } \\
\text { between the parties }\end{array}$ & $\begin{array}{l}\text { agreement reached } \\
\text { between the parties }\end{array}$ & $\begin{array}{l}\text { agreement reached } \\
\text { between the parties }\end{array}$ & $\begin{array}{l}\text { agreement reached } \\
\text { between the parties }\end{array}$ & $\begin{array}{l}\text { agreement reached } \\
\text { between the parties }\end{array}$ \\
\hline 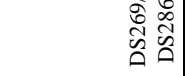 & EC-Chicken Cuts & & yes & yes & & yes & & yes $(\mathrm{S})$ & & & \\
\hline 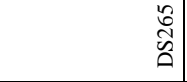 & $\begin{array}{l}\text { EC - Export } \\
\text { Subsidies on Sugar }\end{array}$ & & yes & yes & yes & yes & & yes $(\mathrm{R})$ & yes & & \\
\hline $\begin{array}{l}\widetilde{c} \\
\tilde{n} \\
\hat{n}\end{array}$ & $\begin{array}{l}\text { Dominican } \\
\text { Republic - } \\
\text { Cigarettes }\end{array}$ & $\begin{array}{l}\text { agreement reached } \\
\text { between the parties }\end{array}$ & $\begin{array}{l}\text { agreement reached } \\
\text { between the parties }\end{array}$ & $\begin{array}{l}\text { agreement reached } \\
\text { between the parties }\end{array}$ & $\begin{array}{l}\text { agreement reached } \\
\text { between the parties }\end{array}$ & $\begin{array}{l}\text { agreement reached } \\
\text { between the parties }\end{array}$ & $\begin{array}{l}\text { agreement reached } \\
\text { between the parties }\end{array}$ & $\begin{array}{l}\text { agreement reached } \\
\text { between the parties }\end{array}$ & $\begin{array}{l}\text { agreement reached } \\
\text { between the parties }\end{array}$ & $\begin{array}{l}\text { agreement reached } \\
\text { between the parties }\end{array}$ & $\begin{array}{l}\text { agreement reached } \\
\text { between the parties }\end{array}$ \\
\hline مٌ & US - Gambling & & yes & yes & yes & & yes & & & & \\
\hline
\end{tabular}


PARTICULAR CIRCUMSTANCES RAISED BY THE DEFENDING MEMBER IN ARTICLE 21.3(C) DSU ARBITRATIONS

\begin{tabular}{|c|c|c|c|c|c|c|c|c|c|c|c|}
\hline $\begin{array}{l}\text { Dispute Number } \\
\text { [21.3c)] }\end{array}$ & $\begin{array}{c}\text { Dispute Name } \\
[21.3 c)]\end{array}$ & $\begin{array}{l}\text { Defendant is a } \\
\text { developing country }\end{array}$ & $\begin{array}{l}\text { Implementation } \\
\text { measure is complex }\end{array}$ & $\begin{array}{l}\text { Implementation } \\
\text { process is complex } \\
\text { (multi-step and } \\
\text { sequential process) }\end{array}$ & $\begin{array}{l}\text { Implementation } \\
\text { measure is } \\
\text { contentious } \\
\text { domestically }\end{array}$ & $\begin{array}{c}\text { Standard } \\
\text { legislative and } \\
\text { regulatory } \\
\text { practices linked to } \\
\text { transparency and } \\
\text { due-process are } \\
\text { needed for } \\
\text { implementation }\end{array}$ & $\begin{array}{l}\text { Institutional } \\
\text { changes, elections, } \\
\text { congressional } \\
\text { schedule affect } \\
\text { promptness of } \\
\text { implementation }\end{array}$ & $\begin{array}{c}\text { Broader legislative } \\
\text { or regulatory } \\
\text { reform, or support } \\
\text { measures are needed } \\
\text { for full } \\
\text { implementation } \\
\text { (r)=(reform),(s)=(su } \\
\text { pplementary } \\
\text { means),(b)=(both) }\end{array}$ & $\begin{array}{c}\text { Structural market } \\
\text { imbalanceas and } \\
\text { domestic } \\
\text { adjustments should } \\
\text { be accounted for }\end{array}$ & $\begin{array}{l}\text { Workload of } \\
\text { implementing } \\
\text { authority affects } \\
\text { implementation }\end{array}$ & $\begin{array}{l}\text { Risk-assessment is } \\
\text { needed to full } \\
\text { implementation }\end{array}$ \\
\hline 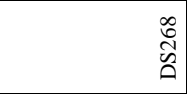 & \begin{tabular}{|l} 
US - Oil Country \\
Tubular Goods \\
Sunset Reviews
\end{tabular} & & yes & yes & & yes & & & & & \\
\hline ț & $\begin{array}{l}\text { US - Softwood } \\
\text { Lumber V }\end{array}$ & $\begin{array}{l}\text { agreement reached } \\
\text { between the parties }\end{array}$ & $\begin{array}{l}\text { agreement reached } \\
\text { between the parties }\end{array}$ & $\begin{array}{l}\text { agreement reached } \\
\text { between the parties }\end{array}$ & $\begin{array}{l}\text { agreement reached } \\
\text { between the parties }\end{array}$ & $\begin{array}{l}\text { agreement reached } \\
\text { between the parties }\end{array}$ & $\begin{array}{l}\text { agreement reached } \\
\text { between the parties }\end{array}$ & $\begin{array}{l}\text { agreement reached } \\
\text { between the parties }\end{array}$ & $\begin{array}{l}\text { agreement reached } \\
\text { between the parties }\end{array}$ & $\begin{array}{l}\text { agreement reached } \\
\text { between the parties }\end{array}$ & $\begin{array}{l}\text { agreement reached } \\
\text { between the parties }\end{array}$ \\
\hline 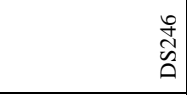 & \begin{tabular}{|l} 
EC-Tariff \\
Preferences
\end{tabular} & & yes & yes & & yes & yes & yes (B) & & & \\
\hline 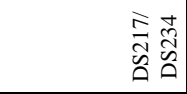 & $\begin{array}{l}\text { US - Offset Act } \\
\text { (Byrd Amendment) }\end{array}$ & & yes & yes & yes & yes & yes & & & & \\
\hline 今ે & $\begin{array}{l}\text { Chile - Price Band } \\
\text { System }\end{array}$ & yes & yes & yes & yes & yes & & yes (B) & & & \\
\hline 今ิ & US - Line Pipe & $\begin{array}{l}\text { agreement reached } \\
\text { between the parties }\end{array}$ & $\begin{array}{l}\text { agreement reached } \\
\text { between the parties }\end{array}$ & $\begin{array}{l}\text { agreement reached } \\
\text { between the parties }\end{array}$ & $\begin{array}{l}\text { agreement reached } \\
\text { between the parties }\end{array}$ & $\begin{array}{l}\text { agreement reached } \\
\text { between the parties }\end{array}$ & $\begin{array}{l}\text { agreement reached } \\
\text { between the parties }\end{array}$ & $\begin{array}{l}\text { agreement reached } \\
\text { between the parties }\end{array}$ & $\begin{array}{l}\text { agreement reached } \\
\text { between the parties }\end{array}$ & $\begin{array}{l}\text { agreement reached } \\
\text { between the parties }\end{array}$ & $\begin{array}{l}\text { agreement reached } \\
\text { between the parties }\end{array}$ \\
\hline 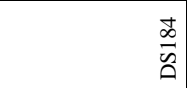 & $\begin{array}{l}\text { US - Hot-Rolled } \\
\text { Steel }\end{array}$ & & yes & yes & & yes & yes & & & & \\
\hline$\frac{n}{n}$ & $\begin{array}{l}\text { Argentina - Hides } \\
\text { and Leather }\end{array}$ & yes & yes & yes & yes & & & yes (B) & & & \\
\hline$\frac{2}{n}$ & $\begin{array}{l}\text { Canada-Patent } \\
\text { Term }\end{array}$ & & & & yes & yes & yes & & & & \\
\hline 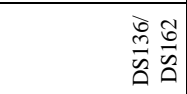 & US - 1916 Act (EC) & & yes & yes & & & yes & & & & \\
\hline$\frac{b}{0}$ & $\begin{array}{l}\text { US - Section 110(5) } \\
\text { Copyright Act }\end{array}$ & & & yes & yes & & yes & & & yes & \\
\hline 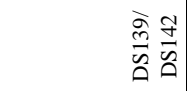 & Canada - Autos & & & yes & & yes & & yes (B) & & & \\
\hline 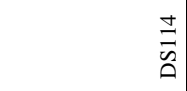 & $\begin{array}{l}\text { Canada- } \\
\text { Pharmaceuticals }\end{array}$ & & & yes & & yes & yes & & & & \\
\hline 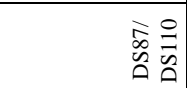 & $\begin{array}{l}\text { Chile - Alcoholic } \\
\text { Beverages }\end{array}$ & yes & yes & yes & yes & yes & & & & & \\
\hline
\end{tabular}


PARTICULAR CIRCUMSTANCES RAISED BY THE DEFENDING MEMBER IN ARTICLE 21.3(C) DSU ARBITRATIONS

\begin{tabular}{|c|c|c|c|c|c|c|c|c|c|c|c|}
\hline $\begin{array}{l}\text { Dispute Number } \\
[21.3 \mathrm{c})]\end{array}$ & $\begin{array}{l}\text { Dispute Name } \\
\text { [21.3c)] }\end{array}$ & $\begin{array}{c}\text { Defendant is a } \\
\text { developing countrv }\end{array}$ & $\begin{array}{c}\text { Implementation } \\
\text { measure is complex }\end{array}$ & $\begin{array}{l}\text { Implementation } \\
\text { process is complex } \\
\text { (multi-step and } \\
\text { sequential process) }\end{array}$ & $\begin{array}{l}\text { Implementation } \\
\text { measure is } \\
\text { contentious } \\
\text { domestically }\end{array}$ & $\begin{array}{c}\text { Standard } \\
\text { legislative and } \\
\text { regulatory } \\
\text { practices linked to } \\
\text { transparency and } \\
\text { due-process are } \\
\text { needed for } \\
\text { implementation }\end{array}$ & $\begin{array}{c}\text { Institutional } \\
\text { changes, elections, } \\
\text { congressional } \\
\text { schedule affect } \\
\text { promptness of } \\
\text { implementation }\end{array}$ & $\begin{array}{c}\text { Broader legislative } \\
\text { or regulatory } \\
\text { reform, or support } \\
\text { measures are needed } \\
\text { for full } \\
\text { implementation } \\
(\mathbf{r})=(\text { reform }),(\mathrm{s})=(\mathrm{su} \\
\text { pplementary } \\
\text { means),(b) }=(\text { both) }\end{array}$ & $\begin{array}{c}\text { Structural market } \\
\text { imbalanceas and } \\
\text { domestic } \\
\text { adjustments should } \\
\text { be accounted for }\end{array}$ & $\begin{array}{c}\text { Workload of } \\
\text { implementing } \\
\text { authority affects } \\
\text { implementation }\end{array}$ & $\begin{array}{l}\text { Risk-assessment is } \\
\text { needed to full } \\
\text { implementation }\end{array}$ \\
\hline 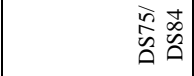 & $\begin{array}{l}\text { Korea -Alcoholic } \\
\text { Beverages }\end{array}$ & & yes & yes & & & & yes $(S)$ & & & \\
\hline$\frac{\infty}{\tilde{n}}$ & Australia - Salmon & & & & & & & & & & yes \\
\hline 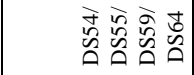 & Indonesia - Autos & & yes & yes & yes & yes & & & yes & & \\
\hline 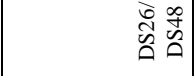 & $E C$ - Hormones & & & yes & & yes & yes & & & & yes \\
\hline$\hat{\tilde{\omega}}$ & $E C$ - Bananas III & & yes & yes & yes & yes & & & & & \\
\hline 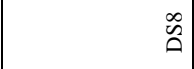 & $\begin{array}{l}\text { Japan - Alcoholic } \\
\text { Beverages II }\end{array}$ & & & yes & yes & & yes & yes $(S)$ & yes & & \\
\hline $\begin{array}{l}\text { Frequency (\% of } \\
\text { times raised by } \\
\text { defending } \\
\text { Members) }\end{array}$ & & $20 \%$ of all disputes & $70 \%$ of all disputes & $\begin{array}{l}93,3 \% \text { of all } \\
\text { disputes }\end{array}$ & $\begin{array}{l}43.3 \% \text { of all } \\
\text { disputes }\end{array}$ & $\begin{array}{l}63.3 \% \text { of all } \\
\text { disputes }\end{array}$ & $\begin{array}{l}36.6 \% \text { of all } \\
\text { disputes }\end{array}$ & $40 \%$ of all disputes & $10 \%$ of all disputes & $13.3 \%$ of all disputes & $6.6 \%$ of all disputes \\
\hline
\end{tabular}




\section{Author contacts:}

\section{Petros C. Mavroidis}

Columbia Law School

435 W. 116th St

New York NY 10027

Email:pmavro@law.columbia.edu

\section{Niall Meagher}

Advisory Centre on WTO Law

1211 Geneva 20

Switzerland

Email: niall.meagher@acwl.ch

\section{Thomas J. Prusa}

Department of Economics

New Jersey Hall

75 Hamilton St

Rutgers University

New Brunswick

NJ, 08901-1248

Email: prusa@ rutgers.edu

\section{Tatiana Yanguas}

Advisory Centre on WTO Law

1211 Geneva 20

Switzerland

Email: tatiana.yanguas@acwl.ch 